\title{
Kinetics of $\mathrm{OH}+\mathrm{SO}_{2}+\mathrm{M}$ : Temperature-dependent rate coefficients in the fall-off regime and the influence of water vapour
}

\author{
Wenyu Sun, ${ }^{1}$ Matias Berasategui, ${ }^{1}$ Andrea Pozzer, ${ }^{1}$ Jos lelieveld ${ }^{1}$ and John N. Crowley ${ }^{1}$ \\ Atmospheric Chemistry Department, Max-Planck-Institute for Chemistry, 55128 Mainz, Germany \\ 5 Correspondence to: John N. Crowley (John.Crowley@mpic.de)
}

\begin{abstract}
The $\mathrm{OH}$-initiated oxidation of $\mathrm{SO}_{2}$ is the dominant, first step in the transformation of this atmospherically important trace-gas to particulate sulphate and accurate rate coefficients for the title reaction under all atmospheric conditions (pressures, temperatures and humidity) are required to assess its role in e.g. new particle formation. Prior to this study, no temperature dependent data were available in the fall-off regime for atmospherically relevant bath-gases. We thus address an important omission in the kinetic database for this reaction and highlight significant discrepancies in recommended parameterizations. In this work, generation of $\mathrm{OH}$ via pulsed laser photolysis at 248 and $351 \mathrm{~nm}$ was coupled to its detection by laser induced fluorescence to obtain rate coefficients $\left(k_{1}\right)$ for the title reaction at pressures of $14-742$ Torr and temperatures of $220-333 \mathrm{~K}$ in $\mathrm{N}_{2}$ bath gas. In-situ $\mathrm{SO}_{2}$ concentrations, central to accurate kinetic measurements under pseudo-first-order conditions, were measured by optical absorption. Under the conditions of the present study, the termolecular reaction between $\mathrm{OH}_{\text {and }} \mathrm{SO}_{2}$ is

15 in the fall-off regime and we parameterized the rate coefficients in $\mathrm{N}_{2}$ in terms of low- $\left(k_{1,0}\right)$ and high-pressure $\left(k_{1, \infty}\right)$ limiting rate coefficients and a broadening factor $\left(F_{\mathrm{C}}\right)$ to obtain $k_{1,0}^{\mathrm{N} 2}=3.03 \times 10^{-31}(\mathrm{~T} / 300)^{-4.10} \mathrm{~cm}^{6} \mathrm{molecule}^{-2} \mathrm{~s}^{-1}, k_{1, \infty}=2.00 \times 10^{-12} \mathrm{~cm}^{3}$ molecule ${ }^{-1} \mathrm{~s}^{-1}$, and $F_{\mathrm{C}}=0.58$. The effects of water vapour on the title reaction were explored through measurements in $\mathrm{N}_{2}-\mathrm{H}_{2} \mathrm{O}$ mixtures at 273, 298 and $333 \mathrm{~K}$ using the same experimental methods. The rate coefficients are significantly enhanced by the presence of water vapour with $k_{1,0}^{\mathrm{H} 2 \mathrm{O}}=1.65 \times 10^{-30} \mathrm{~cm}^{6}$ molecule $\mathrm{e}^{-2} \mathrm{~s}^{-1}$, which indicates that $\mathrm{H}_{2} \mathrm{O}$ is a factor $>5$ more efficient in

20 quenching the $\mathrm{HOSO}_{2}$ * association complex than $\mathrm{N}_{2}$. A model-based comparison of our rate coefficients and parameterization with previous literature measurements and recommendations of evaluation panels are presented and discussed. The use of the new parameterization instead of the IUPAC or NASA evaluations, particularly after including $\mathrm{H}_{2} \mathrm{O}$ as a third-body quencher, leads to a significant (10-30\%) reduction in the lifetime of $\mathrm{SO}_{2}$ in some parts of the atmosphere and increases the $\mathrm{H}_{2} \mathrm{SO}_{4} / \mathrm{SO}_{2}$ ratio concomitantly.
\end{abstract}

\section{Introduction}

Sulphur enters the atmosphere predominantly in the form of gaseous sulphur dioxide $\left(\mathrm{SO}_{2}\right)$ which results from both natural and anthropogenic sources (Stevenson et al., 2003). The amount of $\mathrm{SO}_{2}$ produced from human activities, particularly via fossil fuel combustion, is similar to that resulting from natural emissions (e.g. volcanic eruptions), and can be dominant on a regional scale (Brown, 1982; Brimblecombe, 2013; Lelieveld et al., 1997). $\mathrm{SO}_{2}$ is a key intermediate during the complex chemical and 
30 photochemical reactions that ultimately transform reduced sulphur compounds to sulphates. The oxidation of $\mathrm{SO}_{2}$ in the atmosphere occurs in the gas phase as well as in droplets and aerosol particles (Liu et al., 2020; Cox, 1979; Beilke and Gravenhorst, 1978). The gas-phase oxidation of $\mathrm{SO}_{2}$ is initiated mainly by the $\mathrm{OH}$ radical (R1), with a small contribution in forested regions by stabilised Criegee intermediates (Mauldin Iii et al., 2012; Huang and Chao, 2015). Based on a seasonal, global average boundary layer $\mathrm{OH}$ concentration of $1 \times 10^{6}$ molecule $\mathrm{cm}^{-3}$ and the present recommendation for the rate coefficient (Atkinson et al., 2004; Iupac, 2021), the lifetime of $\mathrm{SO}_{2}$ with respect to reaction with $\mathrm{OH}$ (to form $\mathrm{HOSO}_{2}$ ) is a few days.

$\mathrm{SO}_{2}+\mathrm{OH}+\mathrm{M} \quad \rightarrow \quad \mathrm{HOSO}_{2}+\mathrm{M}$

Once collisionally stabilized $\mathrm{HOSO}_{2}$ reacts with $\mathrm{O}_{2}$ to form $\mathrm{SO}_{3}(\mathrm{R} 2)$, which is hydrolysed to sulphuric acid $\left(\mathrm{H}_{2} \mathrm{SO}_{4}\right)(\mathrm{R} 3)$.

$\mathrm{HOSO}_{2}+\mathrm{O}_{2} \quad \rightarrow \quad \mathrm{HO}_{2}+\mathrm{SO}_{3}$

$40 \mathrm{SO}_{3}+\left(\mathrm{H}_{2} \mathrm{O}\right)_{\mathrm{n}} \quad \rightarrow \quad \mathrm{H}_{2} \mathrm{SO}_{4}+\left(\mathrm{H}_{2} \mathrm{O}\right)_{\mathrm{n}-1}$

$\mathrm{H}_{2} \mathrm{SO}_{4}$ can initiate particle formation (e.g. via reactions with basic trace-gases such as $\mathrm{NH}_{3}$ ) or condense on existing particles, thus contributing to aerosol formation, growth and cloud droplet nucleation (Kulmala et al., 1998; Vehkamäki et al., 2002; Sipilä et al., 2010; Saltzman et al., 1983). The aforementioned processes occur throughout the atmosphere, affecting ecosystems as well as the earth troposphere radiation budget and thus climate (Badr and Probert, 1994; Lelieveld and

45 Heintzenberg, 1992; Stevenson et al., 2003; Feichter et al., 1996). In addition, the oxidation of $\mathrm{SO}_{2}$ to sulphate is a major sink of stratospheric $\mathrm{OH}$ and water (Bekki, 1995) and provides surface area for heterogeneous processes that e.g. contribute to stratospheric ozone depletion (Weisenstein et al., 1996; Heckendorn et al., 2009).

As a result of its central importance to atmospheric chemistry, the kinetics of the title reaction have been investigated in numerous experimental studies. The results of laboratory investigations of $k_{1}$, which serve as the basis for the IUPAC (Iupac,

50 2021) and NASA (Burkholder et al., 2020) evaluation panels, are summarized in Table 1. A few early measurements of $k_{1}$ at around $298 \mathrm{~K}$ and 1 atm N $\mathrm{N}_{2}$ (or air) (Izumi et al., 1984; Barnes et al., 1986; Davis et al., 1979; Castleman Jr and Tang, 1976; Cox and Sheppard, 1980) are not included in Table 1, as they do not contain information on the pressure- or temperaturedependence of the title reaction and display relatively large differences in $k_{1}$ at $298 \mathrm{~K}$ and $1 \mathrm{~atm}$ with values ranging from $5.99 \times 10^{-13}$ to $1.22 \times 10^{-12} \mathrm{~cm}^{3}$ molecule ${ }^{-1} \mathrm{~s}^{-1}$. Surprisingly, for such an important reaction in atmospheric chemistry, no

55 temperature-dependent measurements of $k_{1}$ in the fall-off regime have been carried out in atmospherically relevant bath gases (e.g. air or $\mathrm{N}_{2}$ ) but in He for which the collision efficiency is much lower than for $\mathrm{N}_{2}$ and $\mathrm{O}_{2}$, the dominant components of the atmosphere. In addition, the latest measurements of $k_{1}$, (Blitz et al., 2017a) using modern, laser-based photolysis methods, suggest that previous measurements were strongly biased (to larger values) by the photo-excitation of $\mathrm{SO}_{2}$ (see later).

The title reaction is in the fall-off regime across the temperature/pressure ranges in the atmosphere. To parameterize the rate 60 coefficients for such reactions, the Troe-type formulation (Troe, 1983) is widely-used, which requires experimentallydetermined high-pressure $\left(k_{1, \infty}\right.$ and low-pressure $\left(k_{1,0}\right)$ limiting rate coefficients as well as a broadening factor describing the transition at intermediate pressures. To date, the rate coefficient at the high-pressure limit has not been measured directly and the value of $k_{1}$ at $298 \mathrm{~K}$ of $\sim 2.4 \times 10^{-12} \mathrm{~cm}^{3}$ molecule $^{-1} \mathrm{~s}^{-1}$ at 96 bar (72000 Torr) of He, the highest pressure explored to date, is 
still below the extrapolated $k_{1, \infty}$ value of $3.6 \times 10^{-12} \mathrm{~cm}^{3}$ molecule $\mathrm{s}^{-1}$ (Fulle et al., 1999). (Blitz et al., 2017a) derived values of

$k_{1, \infty}$ indirectly via measurements of the vibrational relaxation of $\mathrm{OH}$ in collision with $\mathrm{SO}_{2}$, but obtained a much lower value of $k_{1, \infty}=7.2 \times 10^{-13} \mathrm{~cm}^{3}$ molecule ${ }^{-1} \mathrm{~s}^{-1}$. The value of $k_{1, \infty}$ presently recommended by IUPAC (last updated in November 2017) and NASA (last updated in May 2020) are $2.0 \times 10^{-12}$ and $1.7 \times 10^{-12} \mathrm{~cm}^{3}$ molecule $\mathrm{e}^{-1}$, respectively, falling between those of (Fulle et al., 1999) and (Blitz et al., 2017a).

From the studies reporting low-pressure limiting rate coefficients, largely obtained in flow-tube experiments, it is unclear

70 whether $k_{1,0}$ could be accurately derived through linear fitting to measured values of $k_{1}$ over a small pressure range, as measurements at the experimental pressures (a few Torr) were already impacted by fall-off. As discussed by Amedro et al. (2019), other factors such as wall-losses of $\mathrm{OH}$ add to the difficulty of deriving accurate low-pressure limiting rate coefficients in flow-tube experiments, especially at low temperatures.

Apart from $\mathrm{N}_{2}$ and $\mathrm{O}_{2}$, water vapour $\left(\mathrm{H}_{2} \mathrm{O}\right)$ is a major atmospheric component. In particular, in the relatively warm boundary layer, e.g. in the tropics, the mixing ratio of water vapour can exceed 5\%. For termolecular reactions involving $\mathrm{OH}, \mathrm{H}_{2} \mathrm{O}$ may be expected to be a more efficient third-body quenching agent than $\mathrm{N}_{2}$ and $\mathrm{O}_{2}$ (Troe, 2003; Amedro et al., 2020) and the presence of water vapour can significantly enhance rate coefficients of third-body reactions in the low-pressure and fall-off regimes. A recent study (Amedro et al., 2020) demonstrated that neglecting to consider the influence of water vapour would lead to an underestimation in the rate coefficients of the $\mathrm{OH}+\mathrm{NO}_{2}$ reaction by $\sim 10 \%$ in some parts of the lower atmosphere.

80 Given the similarities between the title reaction and the $\mathrm{OH}+\mathrm{NO}_{2}$ reaction, the participation of $\mathrm{H}_{2} \mathrm{O}$ as a third-body quencher may also significantly enhance $k_{1}$, and such effects need to be examined experimentally.

The goals of this study were to address some of the shortcomings in the present dataset on the reaction of $\mathrm{OH}$ with $\mathrm{SO}_{2}$ by accurately measuring $k_{1}$ in $\mathrm{N}_{2}$ bath gas over a wide temperature/pressure range relevant for the atmosphere and to elucidate the role of water vapour as a third-body quencher on the title reaction. Such datasets are expected to yield a new parameterization for $k_{1}$ with reduced uncertainties.

\section{Experimental methods}

Rate coefficients for the title reaction were derived using the pulsed-laser-photolysis (PLP)-laser induced fluorescence (LIF) technique under pseudo-first-order conditions ([ $\left.\mathrm{SO}_{2}\right]$ >> [OH], see Section 3.2). The concentrations of $\mathrm{SO}_{2}$, as well as $\mathrm{H}_{2} \mathrm{O}$ in the experiments exploring the effect of water vapour, were obtained online via optical absorption measurements.

\section{$90 \quad 2.1$ PLP-LIF technique}

Detailed descriptions of the PLP-LIF setup are given in previous publications (Wollenhaupt et al., 2000; Amedro et al., 2019). Briefly, the reaction took place in a jacketed quartz reactor with a volume of $\sim 500 \mathrm{~cm}^{3}$, the temperature inside the reactor was regulated by circulating ethanol (at $220 \mathrm{~K}$ ) or 60:40 ethylene glycol mixture (250, 273 and $333 \mathrm{~K}$ ) through an outer jacket. The temperature at the centre of the reaction volume was monitored by a J-type thermocouple before and after each experiment; 
95 the pressure was measured using 100 and 1000 Torr capacitance manometers. To ensure that a fresh gas sample was photolysed at each laser pulse (laser frequency: $10 \mathrm{~Hz}$ ) and to avoid accumulation of products, the average linear-velocity of gas flowing through the reactor was kept at $\sim 8-9 \mathrm{~cm} \mathrm{~s}^{-1}$ by adjusting the total volume flow rates according to the pressure and temperature in the reactor. For the vast majority of experiments, a KrF excimer laser (COMPex 205F, Coherent) provided pulses of 248 nm light ( $\sim 20 \mathrm{~ns}$ ) to photolyse $\mathrm{H}_{2} \mathrm{O}_{2}$ or $\mathrm{HNO}_{3}$ for the generation of $\mathrm{OH}$ radicals in the vibrational ground-state (Schiffman et al., 1993).

$\mathrm{H}_{2} \mathrm{O}_{2}+h v(248 \mathrm{~nm}) \quad \rightarrow \quad 2 \mathrm{OH}$

$\mathrm{HNO}_{3}+h v(248 \mathrm{~nm}) \quad \rightarrow \quad \mathrm{OH}+\mathrm{NO}_{2}$

In addition, a limited set of experiments were carried out in which HONO was photolysed at $351 \mathrm{~nm}$ (XeF excimer laser):

$\mathrm{HONO}+h v(351 \mathrm{~nm}) \quad \rightarrow \quad \mathrm{OH}+\mathrm{NO}$

105 OH radicals thus generated were excited at $282 \mathrm{~nm}\left(\mathrm{~A}^{2} \Sigma(v=1) \leftarrow \mathrm{X}^{2} \Pi(v=0)\right)$ by a YAG-pumped dye-laser and the subsequent OH fluorescence was detected by a photomultiplier placed behind a $309 \mathrm{~nm}$ interference filter and a BG 26 glass cut-off filter. The photolysis laser fluence was measured by a Joule-meter placed behind the exit window of the reactor, and the shot-to-shot variation in the intensity of the dye-laser was monitored by a photodiode. The timing between the triggers of the photolysis and probe lasers was scanned using a digital delay generator; time-dependent $\mathrm{OH}$ profiles were obtained by accumulating the

110 fluorescence signals using a boxcar integrator. Fluorescence resulting from the excitation of $\mathrm{SO}_{2}$ at $282 \mathrm{~nm}$ was also observed using this set-up, which results in a constant background signal during each experiment. Typically, 20 points were recorded before triggering the excimer laser to measure the background signal which also includes a component from electronic noise. The background signal was subtracted from the measured $\mathrm{OH}$ profile before further kinetic analyses.

\subsection{On-line optical absorption measurements}

115 The accurate determination of the rate coefficients under pseudo-first-order conditions requires reliable quantification of $\mathrm{SO}_{2}$

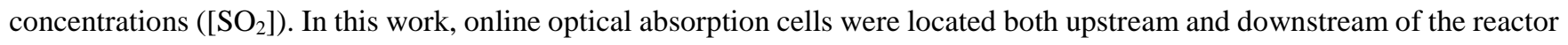
to monitor the $\mathrm{SO}_{2}$ concentration at room temperature (298 K). Upstream of the reactor, light from a deuterium lamp was directed through a multi-pass absorption cell $(l=110 \mathrm{~cm} \times 8=880 \mathrm{~cm})$ and detected by a low resolution $(\Delta \lambda=2 \mathrm{~nm})$ spectrograph (Ocean-Optics USB 2000). The measured optical density over the wavelength range of 240-325 nm was fit to a

120 reference spectrum (Manatt and Lane, 1993) to derive $\mathrm{SO}_{2}$ concentrations. The second (downstream) optical absorption cell ( $l$ $=34.8 \mathrm{~cm}$ ) was equipped with a low-pressure Zinc lamp and monitored optical density at $213.86 \mathrm{~nm}$ to measure the concentration of $\mathrm{SO}_{2}$ (see Section 3.1) and the $\mathrm{OH}$ precursors $\mathrm{H}_{2} \mathrm{O}_{2}$ and $\mathrm{HNO}_{3} . \mathrm{SO}_{2}$ concentrations were calculated using a $213.86 \mathrm{~nm}$ cross-section derived in separate experiments (see later). Concentrations of $\mathrm{H}_{2} \mathrm{O}_{2}$ and $\mathrm{HNO}_{3}$ were calculated using $\sigma_{213.86 \mathrm{~nm}}\left(\mathrm{H}_{2} \mathrm{O}_{2}\right)=3.30 \times 10^{-19}$ (Vaghjiani and Ravishankara, 1989) and $\sigma_{213.86 \mathrm{~nm}}\left(\mathrm{HNO}_{3}\right)=4.52 \times 10^{-19}$ (Dulitz et al., 2018).

125 Approximate, initial concentrations of $\mathrm{OH}$ radicals were calculated from the precursor concentrations and the excimer laser fluence as recorded by the Joule-meter. A third absorption cell $(l=40 \mathrm{~cm}$, located downstream of the $213.86 \mathrm{~nm}$ cell $)$ equipped 
https://doi.org/10.5194/acp-2021-1074

Atmospheric

Preprint. Discussion started: 9 February 2022

(c) Author(s) 2022. CC BY 4.0 License.

Chemistry

(c) (i)

and Physics

Discussions

with a low-pressure $184.95 \mathrm{~nm} \mathrm{Hg} \mathrm{lamp} \mathrm{as} \mathrm{light} \mathrm{source} \mathrm{was} \mathrm{additionally} \mathrm{used} \mathrm{in} \mathrm{the} \mathrm{experiments} \mathrm{exploring} \mathrm{the} \mathrm{impact} \mathrm{of} \mathrm{water}$ vapour. In this case, a cross section of $\sigma_{184.95} \mathrm{~nm}\left(\mathrm{H}_{2} \mathrm{O}\right)=7.14 \times 10^{-20}$ (Cantrell et al., 1997) was used.

\subsection{Chemicals}

130 Nitrogen ( $\mathrm{N}_{2}, 99.999 \%$ ) was supplied by Westfalen and used without further purification. $\mathrm{SO}_{2}$ (Merck, 99.8\%) was diluted in $\mathrm{N}_{2}$ and stored in a stainless-steel cylinder. Hydrogen peroxide $\left(\mathrm{H}_{2} \mathrm{O}_{2}\right.$, AppliChem, $\left.35 \%\right)$ was vacuum distilled to $>90$ wt. $\%$ purity. Anhydrous $\mathrm{HNO}_{3}$ was synthesized by mixing potassium nitrate $\left(\mathrm{KNO}_{3}\right.$, Sigma-Aldrich, $\left.99 \%\right)$ and sulphuric acid $\left(\mathrm{H}_{2} \mathrm{SO}_{4}\right.$, Roth, 98\%), and condensing the $\mathrm{HNO}_{3}$ vapour in a trap cooled with liquid nitrogen. Distilled water (Merck, liquid chromatography grade) was degassed before use.

\section{$135 \quad 3$ Results and discussion}

\subsection{Quantification of $\mathrm{SO}_{2}$ concentrations}

$\mathrm{SO}_{2}$ absorption spectra over 170-330 $\mathrm{nm}$ at room temperature are presented in Fig. 1, including a low-resolution $(\Delta \lambda=0.1$ $\mathrm{nm})$ datasets reviewed and compiled by Manatt and Lane (1993) and a set of higher-resolution data $\left(\Delta \lambda=2.5 \times 10^{-4} \mathrm{~nm}\right)$ spanning 198-325 nm reported by Stark and co-workers (Stark et al., 1999; Rufus et al., 2003). The two absorption bands (240-330 nm and 170-230 nm) correspond to the $\tilde{\mathrm{B}}\left({ }^{1} \mathrm{~B}_{1}\right) \leftarrow \tilde{\mathrm{X}}\left({ }^{1} \mathrm{~A}_{1}\right)$ and the $\tilde{\mathrm{C}}\left({ }^{1} \mathrm{~B}_{2}\right) \leftarrow \tilde{\mathrm{X}}\left({ }^{1} \mathrm{~A}_{1}\right)$ transitions, respectively (Rollins et al., 2016). The high-resolution measurements by Stark et al. (1999) reveal very narrow rotational-vibrational lines in the 200-220 nm region, and cross-sections that are factors of 2-3 larger than those of Manatt and Lane (1993). Clearly, the use of an inappropriate cross section at the wavelength of our very narrow Zn-atomic emission line ( 213.86 nm) could introduce large uncertainty in $\mathrm{SO}_{2}$ concentration. For this reason, we derived an effective cross-section for our Zn-lamp emission by comparing absorption measurements in the multi-pass cell and the $213.86 \mathrm{~nm}$ cell for a flowing gas-mixture of $\mathrm{SO}_{2}$ in $\mathrm{N}_{2}$. We refer to this cross-section as an "effective" cross-section as nearby, weaker atomic lines will also pass through the interference filter (214 $\pm 5 \mathrm{~nm}$ ) used to isolate the $213.86 \mathrm{~nm}$ line. In Fig. 1, broadband (240-325 nm, resolution $2 \mathrm{~nm}$ ) absorption measurements recorded using the multi-pass cell are compared to the reference spectrum of Manatt and Lane (1993). SO concentrations were determined through least squares fitting the measured optical density to the reference spectrum degraded

150 to the same resolution as our spectrometer. The effective cross section at $213.86 \mathrm{~nm}$ was then derived according to the BeerLambert law, taking into account pressure differences in the two absorption cells, as shown in Fig. 2. The slope of a linear regression through the data points is the effective cross-section of $\mathrm{SO}_{2}$ at the emission wavelength of our low-pressure $\mathrm{Zn}$ Lamp. The value obtained $\left(4.00 \times 10^{-18} \mathrm{~cm}^{2}\right.$ molecule $\left.{ }^{-1}\right)$ is very close (within $3 \%$ ) to the value of $4.07 \times 10^{-18} \mathrm{~cm}^{2}$ molecule $^{-1}$ listed at $213.86 \mathrm{~nm}$ by Stark et al. (1999) and the value of $3.87 \times 10^{-18} \mathrm{~cm}^{2}$ molecule-1 derived by Wine et al. (1984) using a

155 similar experimental setup. The high correlation coefficient $\left(\mathrm{R}^{2}\right.$ of 0.9984$)$ for the linear regression of all data points obtained at different pressures (41 to 494 Torr) indicates that the effective value of $\sigma_{213.86}\left(\mathrm{SO}_{2}\right)$ is independent of pressure. $\mathrm{SO}_{2}$ 
concentration measurements using the two absorption cells in the experiments at different temperatures are plotted in Fig. 3. The good agreement (slope very close to 1 ) between the measured (at room temperature) $\mathrm{SO}_{2}$ concentrations upstream and downstream of the reactor (held at temperatures between 220 and $333 \mathrm{~K}$ ) shows that no $\mathrm{SO}_{2}$ is lost in transit (e.g. via adsorption to surfaces or condensation) through the cold/hot reactor. The scatter in this plot is caused by small baseline shifts in the long path measurements upstream of the reactor.

\subsection{Rate coefficients for the title reaction in $\mathrm{N}_{2}$}

Rate coefficients for the title reaction in $\mathrm{N}_{2}$ bath were measured at pressures between 14 and 742 Torr at five different temperatures (220, 250, 273, 298 and $333 \mathrm{~K}$ ). In deriving a parameterisation for the rate coefficient in air (see later), we assume that, as is the case for the vast majority of termolecular reactions, $\mathrm{N}_{2}$ and $\mathrm{O}_{2}$ (the major components of air) have the same collisional quenching efficiency. In all experiments, the initial $\mathrm{OH}$ concentration was kept sufficiently low $\left(10^{11}-10^{12}\right.$ molecule $\left.\mathrm{cm}^{-3}\right)$ relative to that of $\mathrm{SO}_{2}\left(6 \times 10^{14}\right.$ to $6 \times 10^{15}$ molecule $\left.\mathrm{cm}^{-3}\right)$ so that pseudo-first-order conditions applied and the decay of $\mathrm{OH}$ may be described by:

$[\mathrm{OH}]_{\mathrm{t}}=[\mathrm{OH}]_{0}\left(-k^{\prime} t\right)$

where $[\mathrm{OH}]_{\mathrm{t}}$ is the $\mathrm{OH}$ concentration at time $t$ after the photolysis laser pulse and $k^{\prime}$ is the pseudo-first-order rate coefficient defined as

$k^{\prime}=k_{1}\left[\mathrm{SO}_{2}\right]+k_{\mathrm{d}}$

$k_{1}$ (in $\mathrm{cm}^{3}$ molecule ${ }^{-1} \mathrm{~s}^{-1}$ ) is the bimolecular rate coefficient for the title reaction and $k_{\mathrm{d}}$ (in $\mathrm{s}^{-1}$ ) accounts for the OH removal through reactions with $\mathrm{H}_{2} \mathrm{O}_{2}$ or $\mathrm{HNO}_{3}$ (R7 or R8) as well as $\mathrm{OH}$ loss due to diffusion out of the reaction zone.

$$
\begin{array}{lll}
\mathrm{OH}+\mathrm{H}_{2} \mathrm{O}_{2} & \rightarrow & \mathrm{H}_{2} \mathrm{O}+\mathrm{HO}_{2} \\
\mathrm{OH}+\mathrm{HNO}_{3} & \rightarrow & \mathrm{H}_{2} \mathrm{O}+\mathrm{NO}_{3}
\end{array}
$$

Fig. 4 displays a set of $\mathrm{OH}$ decay profiles at six different $\mathrm{SO}_{2}$ concentrations ranging from 0 to $5.34 \times 10^{15}$ molecule $\mathrm{cm}^{-3}$ at $298 \mathrm{~K}$ in 59.9 Torr $\mathrm{N}_{2}$. $\mathrm{H}_{2} \mathrm{O}_{2}$ was used as $\mathrm{OH}$ precursor in this dataset and the initial $\mathrm{OH}$ concentration was $\sim 4 \times 10^{11}$ molecule $\mathrm{cm}^{-3}$. Each OH decay is the average of 20 measurements taken over a period of $\sim 5$ minutes. For each profile, the decay constant

$180 k^{\prime}$ was obtained through least-squares fitting to Eq. (1). From each set of $\mathrm{OH}$ decays at a given temperature, pressure and bathgas, the associated bimolecular rate coefficient $k_{1}$ was derived using Eq. (2) as shown in Fig. 5 which plots $k$ ' against $\left[\mathrm{SO}_{2}\right]$ at $298 \mathrm{~K}$ at four different pressures.

Previous experimental studies have reported that the photo-excitation of $\mathrm{SO}_{2}$ can have a large impact on the kinetics of $\mathrm{OH}$ loss. To circumvent this, optical filters containing $\mathrm{SO}_{2}$ have been used to reduce the absorption of e.g. light from flash-lamps (160-220 nm) (Paraskevopoulos et al., 1983; Wine et al., 1984). The $248 \mathrm{~nm}$ laser light used in the current set up is beyond the $\mathrm{SO}_{2}$ photodissociation threshold of $219 \mathrm{~nm}$ so single-photon $\mathrm{SO}_{2}$ photodissociation cannot affect the measurements for $k_{1}$. However, using a similar setup at $248 \mathrm{~nm}$, (Blitz et al., 2017b, a) found evidence for two-photon dissociation of $\mathrm{SO}_{2}$ in their experiments in He and reported a high-pressure limiting rate coefficient that is lower (by a factor of 2-5) than all other measurements or recommendations by evaluation panels. Blitz et al. (2017b) suggested that previous measurements were 
biased by additional $\mathrm{OH}$ removal by radical-radical reactions initiated by the two-photon dissociation of $\mathrm{SO}_{2}$. In order to evaluate whether $\mathrm{SO}_{2}$ photoexcitation could have impacted on our measurements of $k_{1}$ in $\mathrm{N}_{2}$, we conducted measurements at $298 \mathrm{~K}$ and 14 Torr in $\mathrm{N}_{2}$ with the excimer laser power varied by a factor of $\sim 14$. Over this energy range, the impact of any two-photon processes would scale by a factor of $\sim 200$. $k_{1}$ was thus measured in a total of 10 experiments, for which $\mathrm{SO}_{2}$ concentrations ranged from $1.2 \times 10^{15}$ to $6.0 \times 10^{15}$ molecule $\mathrm{cm}^{-3}$, the concentration of $\mathrm{H}_{2} \mathrm{O}_{2}$ was kept at around $3 \times 10^{14}$ molecule $\mathrm{cm}^{-3}$, and the laser fluence was varied from $\sim 0.5$ to $\sim 9.5 \mathrm{~mJ} \mathrm{~cm}^{-2}$. Values of $k_{1}$ as a function of the $248 \mathrm{~nm}$ laser fluence are displayed in Fig. 6. Our data clearly show that $k_{1}$ is independent of laser fluence (the average value is $1.29 \pm 0.05 \times 10^{-13} \mathrm{~cm}^{3}$ molecule $\mathrm{e}^{-1} \mathrm{~s}^{-1}$ ), suggesting that, under our experimental conditions in $\mathrm{N}_{2}$ bath, secondary reactions between $\mathrm{OH}$ radicals resulting from the photoexcitation of $\mathrm{SO}_{2}$ are insignificant. This observation helps to rule out that single- or two-photon processes involving $\mathrm{SO}_{2}$ excitation or dissociation do not bias the $\mathrm{OH}$ decay and that reactions of $\mathrm{OH}$ with e.g. products of R1 (i.e. $\mathrm{HOSO}_{2}$ ) or reaction with $\mathrm{HO}_{2}$ and $\mathrm{NO}_{3}$ (formed in $\mathrm{R} 7$ and $\mathrm{R} 8$ ) are unimportant. To examine the potential for two-photon photolysis of $\mathrm{SO}_{2}$ in He bath-gas, we added $\mathrm{H}_{2} \mathrm{O}$ to a reaction mixture of $\mathrm{H}_{2} \mathrm{O}_{2}, \mathrm{SO}_{2}$ and $\mathrm{He}$ and observed non-exponential $\mathrm{OH}$ kinetics, suggesting the intermediacy of $\mathrm{O}\left({ }^{1} \mathrm{D}\right)$ :

$\mathrm{SO}_{2}+2 h v \quad \rightarrow \quad \mathrm{O}\left({ }^{1} \mathrm{D}\right)+\mathrm{SO}$

$\mathrm{O}\left({ }^{1} \mathrm{D}\right)+\mathrm{H}_{2} \mathrm{O} \quad \rightarrow \quad 2 \mathrm{OH}$

205 We emphasise that such effects were not seen in $\mathrm{N}_{2}$ bath-gas in which $\mathrm{O}\left({ }^{1} \mathrm{D}\right)$ is rapidly quenched to less reactive $\mathrm{O}\left({ }^{3} \mathrm{P}\right)$. To confirm beyond doubt that our measurements using $248 \mathrm{~nm}$ PLP are not biased by $\mathrm{SO}_{2}$ excitation, an additional experiment was performed (193.2 Torr and $298 \mathrm{~K}$ ) using HONO photolysis at $351 \mathrm{~nm}$ as $\mathrm{OH}$ precursor. At $351 \mathrm{~nm}$ the $\mathrm{SO}_{2}$ absorption cross-section is $\sim 3$ orders of magnitude lower than at $248 \mathrm{~nm}$ and $\mathrm{SO}_{2}$ excitation is negligible. HONO was generated in-situ by the dropwise addition of a $0.1 \mathrm{M} \mathrm{NaNO}_{2}$ solution to a $20 \mathrm{wt}$. $\% \mathrm{H}_{2} \mathrm{SO}_{4}$ solution and the characteristic bands at around 342, 354 and $368 \mathrm{~nm}$ (Stutz et al., 2000) were monitored by the multi-pass optical absorption cell. This setup provided sufficient amounts of HONO $\left(\sim 10^{14}\right.$ molecule $\left.\mathrm{cm}^{-3}\right)$ for kinetic measurements for about 1-1.5 hours after adding a few drops of the $\mathrm{NaNO}_{2}$ solution. Note that the concentration of $\mathrm{H}_{2} \mathrm{O}$ above the $\mathrm{H}_{2} \mathrm{SO}_{4}$ solution is very low, so that these can be considered to be dry experiments (i.e. in $\mathrm{N}_{2}$ bath-gas).

Unlike the $\mathrm{H}_{2} \mathrm{O}_{2}$ and $\mathrm{HNO}_{3}$ sources of $\mathrm{OH}$ described above, the concentration of $\mathrm{HONO}$ was not stable over the time required to measure a series of values of $k^{\prime}$ in the presence of various amounts of $\mathrm{SO}_{2}$. Therefore, measurements of $k$ ' with and without $\mathrm{SO}_{2}$ were conducted intermittently. Fig. 7 displays the measured first-order $\mathrm{OH}$ decay rate constants $\left(k^{\prime}\right)$ with different amounts of $\mathrm{SO}_{2}$ present in the system and over a period of $\sim 2.5$ hours. In the absence of $\mathrm{SO}_{2}$ (blue symbols), the $k$ ' decreased from an initial value of $\sim 2800 \mathrm{~s}^{-1}$ to one of $\sim 800 \mathrm{~s}^{-1}$ at $5200 \mathrm{~s}$. This is mainly due to the reaction of OH with HONO and impurities such as $\mathrm{NO}_{2}$ and $\mathrm{NO}$. After $\sim 5400 \mathrm{~s}$ a few drops of $\mathrm{NaNO}_{2}$ were again added to the $\mathrm{H}_{2} \mathrm{SO}_{4}$ solution and the increase in [HONO] was accompanied by an increase in $k^{\prime}$. The decay in $k$ ' over time was fit with a second-order polynomial function which, via interpolation, was used to calculate the contribution of $\mathrm{OH}$ loss in the absence of $\mathrm{SO}_{2}$ (i.e. $k_{\mathrm{d}}$ ) from the individual values obtained with $\mathrm{SO}_{2}$ present. Based on the loss rate constants in the absence of $\mathrm{SO}_{2}$ and the rate coefficient for reaction of $\mathrm{OH}$ 
with HONO $\left(k_{11}(298 \mathrm{~K})=6.0 \times 10^{-12} \mathrm{~cm}^{3}\right.$ molecule $\left.^{-1} \mathrm{~s}^{-1}\right)$ (Atkinson et al., 2004), we estimate the HONO concentrations to be $\sim 1-5 \times 10^{14}$ molecule $\mathrm{cm}^{-3}$. .

$\mathrm{HONO}+\mathrm{OH} \quad \rightarrow \quad \mathrm{NO}_{2}+\mathrm{H}_{2} \mathrm{O}$

Combined with the photolysis laser fluence of around $1 \mathrm{~mJ} \mathrm{~cm}^{-2}$, this results in an initial $\mathrm{OH}$ concentration of $0.3-1.5 \times 10^{11}$ molecule $\mathrm{cm}^{-3}$. A total of five different $\mathrm{SO}_{2}$ concentrations were used in these experiments, and at each $\mathrm{SO}_{2}$ concentration the measurement of $k^{\prime}$ was repeated four times. The averaged values of $k^{\prime}$, after correction for the contribution from reactions of $\mathrm{OH}$ with $\mathrm{HONO}$ and other impurities as well as diffusion loss of $\mathrm{OH}$, are plotted against $\mathrm{SO}_{2}$ concentration in Fig. 8. A linear regression yields a value of $k_{1}=4.91 \pm 0.13 \times 10^{-13} \mathrm{~cm}^{3}$ molecule $^{-1} \mathrm{~s}^{-1}$. A similar set of experiments at $273 \mathrm{~K}$ and 295 Torr yielded $k_{1}=8.44 \pm 0.19 \times 10^{-13} \mathrm{~cm}^{3}$ molecule $\mathrm{e}^{-1} \mathrm{~s}^{-1}$. Owing to the more convoluted experimental procedure and data analysis and also the larger $\mathrm{OH}$ losses in the absence of $\mathrm{SO}_{2}$, (up to $\sim 3000 \mathrm{~s}^{-1}$ ) the overall uncertainty of the rate coefficient obtained in this manner is larger than those obtained using $\mathrm{H}_{2} \mathrm{O}_{2}$ and $\mathrm{HNO}_{3}$ as $\mathrm{OH}$ precursors and the difference $(\sim 10 \%)$ between the rate constant obtained using the $248 \mathrm{~nm}$ photouch lysis of $\mathrm{H}_{2} \mathrm{O}_{2}$ or $\mathrm{HNO}_{3}$ or $\mathrm{HONO}$ as $\mathrm{OH}$ source is not considered significant. In any case, this level of agreement (combined with the laser fluence variation described above) rules out a bias to $k_{1}$ of the magnitude reported by Blitz et al. (2017b) when working at $248 \mathrm{~nm}$ in $\mathrm{N}_{2}$ bath-gas.

Our measurements of $k_{1}$ obtained in $\mathrm{N}_{2}$ bath (in total $>100$ ) are plotted against the $\mathrm{N}_{2}$ concentration, at five different temperatures in Fig. 9. The rate coefficients and associated experimental conditions are listed in Table S1 in the Supplementary Information. The rate coefficients obtained using $\mathrm{H}_{2} \mathrm{O}_{2}$ and $\mathrm{HNO}_{3}$ as $\mathrm{OH}$ precursors (at 273 and $298 \mathrm{~K}$ ) are indistinguishable from each other, indicating that the rate coefficienty obtained are not influenced by secondary chemistry. The overall uncertainty in the values of $k_{1}$ (using $\mathrm{H}_{2} \mathrm{O}_{2}$ and $\mathrm{HNO}_{3}$ precursors for $\mathrm{OH}$ ) is estimated to be $\sim 7 \%$, which takes into account estimated systematic bias in the $\mathrm{SO}_{2}$ cross-section at $213.86 \mathrm{~nm}$.

The solid lines are fits to the experimental data according to the Troe formalism for termolecular reactions (Troe, 1983).

$k_{1}(T, p)=\frac{k_{1,0}^{\mathrm{N} 2}\left(\frac{T}{300}\right)^{-n}[\mathrm{M}] k_{1, \infty}\left(\frac{T}{300}\right)^{-m}}{k_{1,0}^{\mathrm{N} 2}\left(\frac{T}{300}\right)^{-n}[\mathrm{M}]+k_{1, \infty}\left(\frac{T}{300}\right)^{-m}} F$

245 where $k_{1,0}^{\mathrm{N} 2}\left(\mathrm{~cm}^{6}\right.$ molecule $\left.\mathrm{s}^{-1}\right)$ and $k_{1, \infty}\left(\mathrm{cm}^{3}\right.$ molecule $\left.{ }^{-1} \mathrm{~s}^{-1}\right)$ are the high-pressure and low-pressure limiting rate coefficients, respectively; $T$ is the temperature (K), [M] is the molecular density (molecule $\mathrm{cm}^{-3}$ ), $n$ and $m$ are temperature exponents. The broadening factor $F$ (which accounts for the lower rate coefficients measured in the fall-off regime than predictions by the Lindemann-Hinshelwood mechanism) is expressed as

$\log F=\frac{\log F_{\mathrm{C}}}{1+\left[\log \left(\frac{k_{1,0}^{\mathrm{N} 2}\left(\frac{T}{300}\right)^{-n}[\mathrm{M}]}{k_{1, \infty}\left(\frac{T}{300}\right)^{-m}}\right) / N\right]^{2}}$

250 where $N=0.75-1.27 \log F_{\mathrm{C}}$ and $F_{\mathrm{C}}$ is the broadening factor at the centre of the fall-off curve.

In order to reduce the number of variables when fitting, we assume that $k_{1, \infty}$ is independent of the temperature $(m=0)$. This assumption is reasonable as $m$ is expected to be small and the data at high pressures (neither in this work nor in the literature) do not accurately define this parameter. If all remaining variables $\left(k_{1,0}^{\mathrm{N} 2}, k_{1, \infty}, F_{\mathrm{C}}\right.$ and $\left.m\right)$ are allowed to float, the least-squares 
optimization using Eq. (3) and Eq. (4) gives $k_{1,0}^{\mathrm{N} 2}=3.03 \times 10^{-31} \mathrm{~cm}^{6}$ molecule $\mathrm{e}^{-2} \mathrm{~s}^{-1}, k_{1, \infty}=2.00 \times 10^{-12} \mathrm{~cm}^{3} \mathrm{molecule}^{-1} \mathrm{~s}^{-1}, F_{\mathrm{C}}=$

0.58 and $n=4.10$ (see Table 2, Method 1). These parameters, with an $\mathrm{R}^{2}$ correlation coefficient of over 0.994, accurately reproduce all our measurements in $\mathrm{N}_{2}$ bath gas, as shown in Fig. 9.

As the range of temperatures encountered in the Earth's atmosphere is relative narrow, temperature-dependent forms of $F_{\mathrm{C}}$ are no longer widely used in IUPAC evaluations, though a value of $F_{C}=\exp (-T / 472)$ is still recommended for the reaction between $\mathrm{OH}$ and $\mathrm{SO}_{2}$. We therefore also explored the effect of setting $F_{\mathrm{C}}$ to exp(-T/472) and allowing a smaller set of variables, $k_{1,0}^{\mathrm{N} 2}$, $k_{1, \infty}$ and $n$, to float while fitting. This results in a $20 \%$ higher $k_{1,0}^{\mathrm{N} 2}$ of $3.60 \times 10^{-31} \mathrm{~cm}^{6}$ molecule $^{-2} \mathrm{~s}^{-1}$, an almost identical value of $k_{1, \infty}=2.01 \times 10^{-12} \mathrm{~cm}^{3}$ molecule ${ }^{-1} \mathrm{~s}^{-1}$ and $n=2.86$ (Table 2, method 2). In addition, we examined the effect of varying the parameter $m$ (i.e. making $k_{1, \infty}$ temperature dependent) while $F_{\mathrm{C}}$ was varied (but kept temperature independent). In this case we obtained $k_{1, \infty}=2.03 \times 10^{-12} \mathrm{~cm}^{3}$ molecule $\mathrm{s}^{-1}$ with $m=-0.18$ and a lower value of $k_{1,0}^{\mathrm{N} 2}\left(2.82 \times 10^{-31} \mathrm{~cm}^{6} \mathrm{molecule}^{-2} \mathrm{~s}^{-1}\right)$ with $n=4.34$ (Table 2, Method 3).

265 The quality of the fits obtained using Methods 1, 2 or 3 are very similar (see values for the residual standard deviation and correlation coefficients in Table 2), as highlighted in Fig. S1 of the Supplementary Information where pressure and temperature dependent values of $k_{1}$ calculated using all three methods are plotted along with the experimental data. We also show in Fig. S2 a plot of $k_{1}$ derived using each method versus altitude with the appropriate altitude dependent change in temperature and pressure for a standard atmosphere. Clearly, Methods 1 and 3, which have the lowest residual standard deviations are in excellent agreement throughout the atmosphere, with slight differences to Method 2 in the stratosphere. Interestingly, the pressure and temperature dependence of $k_{1}$ cancel each other in the lowest $10 \mathrm{~km}$ of the Earth's atmosphere, so that $k_{1}$ is roughly constant at a value close to $1 \times 10^{-12} \mathrm{~cm}^{3}$ molecule $\mathrm{e}^{-1} \mathrm{~s}^{-1}$.

For the purpose of modelling the Earth's atmosphere, it is more important to ensure that the data at low and intermediate pressures and temperatures are correctly reproduced by the parameterization, with correct definition of $k_{1, \infty}$ of secondary importance. For this reason, we have chosen to use the parameters derived in Method 1 to calculate $k_{1}$ and to compare with previous datasets and evaluations.

\subsection{Comparison with previous parametrizations for $\mathrm{N}_{2}$ bath-gas}

Despite the importance of the title reaction in the atmosphere there were no prior temperature dependent measurements of $k_{1}$ in atmospherically relevant bath-gases. In experiments designed to define $k_{1,0}$, low-pressure flow-tube studies (Leu, 1982; Lee et al., 1990) measured values of $k_{1}$ at $N_{2}$ pressures between 0.6 and 5 Torr. In order to access $k_{1, \infty}$, (Fulle et al., 1999) performed experiments in He bath-gas at pressures up to 96 bar. However, under all experimental conditions investigated so far, the title reaction is still in the fall-off regime and neither high- nor low- pressure limits for the title reactions have been attained directly, experimentally.

In Table 2 we compare our values of $k_{0}, k_{\infty}, F_{C}, n$ and $m$ obtained in $\mathrm{N}_{2}$ with the IUPAC and NASA expressions (both for $\mathrm{N}_{2}$ 285 bath-gas), as well as parameterizations reported by previous studies (Wine et al., 1984; Fulle et al., 1999; Blitz et al., 2017b), 
which were mostly based on temperature-dependent measurements in other bath gases. The value of $k_{1,0}^{\mathrm{N} 2}$ derived in this work (Method 1) is close to those of $2.8 \times 10^{-31}$ and $2.9 \times 10^{-31} \mathrm{~cm}^{6}$ molecule $\mathrm{e}^{-2} \mathrm{~s}^{-1}$ preferred by IUPAC and NASA, respectively, and the current value of $k_{\infty}$ is identical to the recommendation of $2.0 \times 10^{-12} \mathrm{~cm}^{3}$ molecule $\mathrm{e}^{-1} \mathrm{~s}^{-1}$ by IUPAC; The current value of $n$ is equal to the vlue of 4.1 used in the NASA expression, but larger than the IUPAC preferred value of 2.6 unless we adopt the temperature dependent value for $F_{C}$ which IUPAC uses. In that case our value of $n=2.86$ is close to that of IUPAC. This is readily understood as our value of $F_{C}=0.58$ is very close to the "standard" NASA value of $F_{C}=0.6$.

Figure 10 provides a comparison between our data-points and parameterization (Method 1) with the literature data at $298 \mathrm{~K}$ obtained in $\mathrm{N}_{2}$ (Leu, 1982; Lee et al., 1990; Paraskevopoulos et al., 1983; Wine et al., 1984) and with the IUPAC and NASA evaluations. In Fig. S3 of the Supplementary Information we plot the ratios of literature rate constants obtained at $298 \mathrm{~K}$ in $\mathrm{N}_{2}$ to our parameterisation. Also presented in Fig. 10 is a modified parameterisation based on Blitz et al. (2017b) (master equation analyses of the (Paraskevopoulos et al., 1983) and (Wine et al., 1984) data sets). Note that the curve plotted cannot be reproduced using the parameters listed in Table 2 of Blitz et al. (2017b) but is based on data (listed in Table 2) sent in a personal communication with Mark Blitz and takes care of various errors in the published analysis. The comparison in $\mathrm{N}_{2}$ is restricted to $298 \mathrm{~K}$ as, prior to this study, all temperature dependent studies were performed in $\mathrm{SiF}_{6}$, $\mathrm{He}$ or Ar. In the common pressure range, (in the fall-off regime) our values of $k_{1}$ agree very well with those reported by Paraskevopoulos et al. (1983) and Wine et al. (1984). The fall-off curves described by our parameterization and the IUPAC and NASA recommendations are very similar over this pressure range, though our parameterization gives a slightly higher value of $k_{1}$ (298 K, $1 \mathrm{~atm})\left(1.04 \times 10^{-12} \mathrm{~cm}^{3}\right.$ molecule $\left.\mathrm{s}^{-1}\right)$ than those proposed by IUPAC and NASA $\left(9.38\right.$ and $9.50 \times 10^{-13} \mathrm{~cm}^{3} \mathrm{molecule}^{-1}$ $\mathrm{s}^{-1}$, respectively). In this context, we note that the value of $k_{1, \infty}$ chosen by IUPAC was a compromise between the rate coefficients measured at extended pressures of He by Fulle et al. (1999) and the data from Blitz et al. (2017a). These values are however very divergent with $k_{1, \infty}=3.6 \times 10^{-12} \mathrm{~cm}^{3}$ molecule $\mathrm{e}^{-1} \mathrm{~s}^{-1}$ and $k_{1, \infty}=7.5 \times 10^{-13} \mathrm{~cm}^{3}$ molecule $^{-1} \mathrm{~s}^{-1}$, respectively. We show below, that at $220 \mathrm{~K}$ our value of $k_{1}$ in 400 Torr of $\mathrm{N}_{2}\left(13.71 \pm 0.41 \times 10^{-13} \mathrm{~cm}^{3} \mathrm{molecule}^{-1} \mathrm{~s}^{-1}\right)$ while clearly still in the fall-off regime, is a factor of two larger than the value of $k_{1, \infty}=7.5 \times 10^{-13} \mathrm{~cm}^{3}$ molecule $^{-1} \mathrm{~s}^{-1}$ reported by Blitz et al. (2017a). Similarly, our value obtained using $351 \mathrm{~nm}$ photolysis of $\mathrm{HONO}$ as $\mathrm{OH}$ source (i.e. when $\mathrm{SO}_{2}$ excitation can be ruled out) results in $k_{1}=8.44 \pm 0.19 \times 10^{-13} \mathrm{~cm}^{3}$ molecule $\mathrm{s}^{-1}$ in 295 Torr of $\mathrm{N}_{2}$, again above the high-pressure limit reported by Blitz et al. (2017a). Blitz et al. (2017b) suggested that the larger literature values of $k_{1, \infty}$ available at the time of their study were a result of photo-excitation of $\mathrm{SO}_{2}$. However, our results have clearly shown that a) such effects are absent in $\mathrm{N}_{2}$ bath-gas when using $248 \mathrm{~nm}$ photolysis to generate $\mathrm{OH}$ and b) can be ruled out when working at $351 \mathrm{~nm}$ (see above). The excellent agreement between the present rate coefficients and those obtained previously in $\mathrm{N}_{2}$ at $298 \mathrm{~K}$ (Paraskevopoulos et al., 1983; Wine et al.,

315 1984) using completely different $\mathrm{OH}$ generation methods strongly suggest that data in $\mathrm{N}_{2}$ are unaffected by such processes, though we cannot rule out that they are the cause of the large values of $k_{1, \infty}$ obtained by Fulle et al. (1999) in He. The present and previous datasets in $\mathrm{N}_{2}$ indicate that $k_{1, \infty}$ is close to $2 \times 10^{-12} \mathrm{~cm}^{3}$ molecule $\mathrm{s}^{-1}$. 
At lower pressures, the IUPAC, NASA and the present parameterizations capture the flow-tube measurements at 1 Torr and above (Leu, 1982; Lee et al., 1990), whereas at the very lowest pressures, there is substantial deviation. This is likely to reflect bias in the flow-tube data caused e.g. by wall-losses of $\mathrm{OH}$ and large corrections for axial diffusion.

\subsection{Influence of water vapour on $k 1$}

To examine the effects of water vapour (e.g. as a 3rd-body quenching agent) on the kinetics of the title reaction, $k_{1}$ was measured in $\mathrm{N}_{2}-\mathrm{H}_{2} \mathrm{O}$ mixtures at 273, 298 and $333 \mathrm{~K}$. A total pressure of 50 Torr $\left(\mathrm{N}_{2}+\mathrm{H}_{2} \mathrm{O}\right)$ was chosen for these experiments as sensitivity to a potential increase in $k_{1}$ through the presence of water is highest at conditions far from $k_{1, \infty}$. As described in Section 2.2, both $\mathrm{SO}_{2}$ (at $213.856 \mathrm{~nm}$ ) and $\mathrm{H}_{2} \mathrm{O}$ (at $184.95 \mathrm{~nm}$ ) were monitored online by optical absorption. The large absorption cross section of $\mathrm{HNO}_{3}$ at $184.95 \mathrm{~nm}\left(1.61 \times 10^{-17} \mathrm{~cm}^{2}\right.$ molecule $\left.{ }^{-1}\right)$ (Dulitz et al., 2018) would hinder the accurate determination of the $\mathrm{H}_{2} \mathrm{O}$ concentration and $\mathrm{H}_{2} \mathrm{O}_{2}$ was therefore used as the $\mathrm{OH}$ precursor in all measurements in $\mathrm{N}_{2}-\mathrm{H}_{2} \mathrm{O}$ bathgas. The molar $\mathrm{H}_{2} \mathrm{O}$ mixing ratio in $\mathrm{N}_{2}\left(x_{\mathrm{H}_{2} \mathrm{O}}\right)$ was varied up to 0.2 for measurements at 298 and $333 \mathrm{~K}$, and up to 0.05 at 273 $\mathrm{K}$ to avoid condensation of water in the reactor and optical absorption cells. The results are summarized in Table S2, and measured values of $k_{1}$ are plotted versus $x_{\mathrm{H}_{2} \mathrm{O}}$ in Fig. 11 in which $k_{1}$ is seen to increase with the water content of the bath gas, indicating that $\mathrm{H}_{2} \mathrm{O}$ is a more efficient third-body quencher than $\mathrm{N}_{2}$ for the title reaction. This is illustrated in Fig. 12 where we plot the fall-off curves for $k_{1}$ in $\mathrm{N}_{2}$ and $\mathrm{H}_{2} \mathrm{O}$ bath-gases. We note that, as for examining the water-vapour effect in the $\mathrm{OH}$ $+\mathrm{NO}_{2}$ reaction (Amedro et al., 2020), continuous, in-situ measurement of the $\mathrm{SO}_{2}$ concenration is critical to obtaining the correct result as $\mathrm{SO}_{2}$ concentrations (i.e. optical density at $213.86 \mathrm{~nm}$ ) decreased when $\mathrm{H}_{2} \mathrm{O}$ was added to the flowing $\mathrm{H}_{2} \mathrm{O}_{2}$ /

$335 \mathrm{SO}_{2} / \mathrm{N}_{2}$ mixture. This presumably reflects losses of $\mathrm{SO}_{2}$ on the glass surfaces of the apparatus on which $\mathrm{H}_{2} \mathrm{O}$ would have been adsorbed.

To evaluate the role of water on the rate coefficient of the title reaction, a parameterisation of the 3rd-body effect of $\mathrm{H}_{2} \mathrm{O}$ is required and we adopt the approach used in Amedro et al. (2020) for the $\mathrm{OH}+\mathrm{NO}_{2}$ reaction.

Extending Eq. (3), $k_{1}$ in $\mathrm{N}_{2}-\mathrm{H}_{2} \mathrm{O}$ mixture can be expressed by

$k(T, p)=\frac{\left(x_{\mathrm{N}_{2}} k_{1,0}^{\mathrm{N} 2}\left(\frac{T}{300}\right)^{-n}+x_{\mathrm{H}_{2} \mathrm{O}} k_{1,0}^{\mathrm{H} 2 \mathrm{O}}\left(\frac{T}{300}\right)^{-o}\right)[M] k_{1, \infty}\left(\frac{T}{300}\right)^{-m}}{\left.x_{\mathrm{N}_{2}} k_{1,0}^{\mathrm{N} 2}\left(\frac{T}{300}\right)^{-n}+x_{\mathrm{H}_{2} \mathrm{O}} k_{1,0}^{\mathrm{H} 2 \mathrm{O}}\left(\frac{T}{300}\right)^{-o}\right)[M]+k_{1, \infty}\left(\frac{T}{300}\right)^{-m}} F$

where $x_{\mathrm{H}_{2} \mathrm{O}}$ and $x_{\mathrm{N}_{2}}$ are the mole fraction of $\mathrm{H}_{2} \mathrm{O}$ and $\mathrm{N}_{2}, k_{1,0}^{\mathrm{H} 2 \mathrm{O}}$, is the low-pressure limiting rate coefficients (cm ${ }^{6}$ molecule ${ }^{-2}$ $\mathrm{s}^{-1}$ ) in pure $\mathrm{H}_{2} \mathrm{O}$ and $o$ is a dimensionless temperature exponent. The broadening factor $F$ is then:

$\log F=\frac{\log F_{\mathrm{C}}}{1+\left[\log \left(\frac{\left.\left.x_{\mathrm{N}_{2}} k_{1,0}^{\mathrm{N} 2}\left(\frac{T}{300}\right)^{-n}+x_{\left.\mathrm{H}_{2} \mathrm{O} k_{1,0}^{\mathrm{H}} \mathrm{O}\left(\frac{T}{300}\right)^{-o}\right)[M]}\right) / N\right]^{2}}{k_{1, \infty}\left(\frac{T}{300}\right)^{-m}}\right.\right.}$

Here, the low-pressure limiting rate coefficients in pure $\mathrm{N}_{2}$ and pure $\mathrm{H}_{2} \mathrm{O}$ are linearly mixed and the same value of $F_{C}$ is 345 assumed for simplification. By inputting the values of $k_{1,0}^{\mathrm{N} 2}, k_{1, \infty}, F_{\mathrm{C}}$ and $n$ listed in Table 2 (Method 1), a multivariate, leastsquares fit (solid lines in Fig. 9) results in $k_{1,0}^{\mathrm{H} 2 \mathrm{O}}=1.65 \times 10^{-30} \mathrm{~cm}^{6}$ molecule $\mathrm{s}^{-1}$ and $o=4.90$, indicating that $\mathrm{H}_{2} \mathrm{O}$, as a thirdbody collider, is at least five times more efficient than $\mathrm{N}_{2}$. 
https://doi.org/10.5194/acp-2021-1074

Atmospheric

Preprint. Discussion started: 9 February 2022

(c) Author(s) 2022. CC BY 4.0 License.

Chemistry

(c) (i)

and Physics

Discussions

We also consider the use of different values of $F_{C}$ for $\mathrm{N}_{2}$ and $\mathrm{H}_{2} \mathrm{O}$, which may be more appropriate for bath-gases with distinctly different properties (Burke and Song, 2017) and adopted for the $\mathrm{OH}+\mathrm{NO}_{2}$ reaction in $\mathrm{He}-\mathrm{H}_{2} \mathrm{O}$ mixtures (Amedro et al., 2020).

In the present case, however, $F_{C}$ for $\mathrm{N}_{2}$ is already close to 0.6 , so the differences are expected to be small and the use of the more complex expression for the purpose of atmospheric modelling of the reaction is not warranted. This is detailed in the Supplementary Information.

\subsection{Atmospheric modelling of the $\mathrm{OH}+\mathrm{SO}_{2}$ reaction including the effect of water vapour}

The chemistry and climate simulation model used is EMAC (ECHAM-MESSy) which uses the 5th generation European

355 Centre Hamburg general circulation model (ECHAM5, Roeckner et al. (2006)) as core atmospheric general circulation model (Jöckel et al., 2006; Jöckel et al., 2010). In this study we used EMAC (ECHAM5 version 5.3.02, MESSy version 2.55.0) at T63L47MA-resolution, i.e. with a spherical truncation of T63 ( 1.8 by 1.8 degrees in latitude and longitude) with 47 vertical hybrid terrain following-pressure levels up to $0.01 \mathrm{hPa}$. The model was weakly nudged in spectral space, applying Newtonian relaxation of the parameters temperature, vorticity, divergence and surface pressure to meteorological reanalysis data (Jeuken et al., 1996). The model set-up is identical to the simulation RED presented in Reifenberg et al. (2021) where the model was evaluated against an aircraft campaign over Europe. In addition, the model has been evaluated on many occasions (Pozzer et al., 2012a; Pozzer et al., 2012b; Yan et al., 2019). For additional references, see http://www.messy-interface.org. As in Reifenberg et al. (2021), EMAC was used in a chemical-transport model (Deckert et al., 2011) without feedbacks between photochemistry, radiation and atmospheric dynamics. In this work, we performed three identical simulations for the year 2019 but with three different parameterisations of $k_{1}$ from this work and from the IUPAC and NASA evaluations panels. For the simulations we assume that $\mathrm{O}_{2}$ has the same collisional quenching efficiency as $\mathrm{N}_{2}$ as is for case for nearly all termolecular processes of atmospheric importance.

In Fig. 13, we illustrate the impact of $\mathrm{H}_{2} \mathrm{O}$-vapour on the rate coefficient, by plotting the reduction in $k_{1}$ at the Earth's surface when setting $x_{\mathrm{H} 2 \mathrm{O}}$ to zero relative to using EMAC water-vapour fields. The greatest effect of water vapour on $k_{1}$ is found in warm, tropical regions where an average underestimation of the rate coefficient by up to $\approx 5 \%$ is found when $x_{\mathrm{H} 2 \mathrm{O}}=0$. At higher/lower latitudes the effect is diminished and water vapour accounts for only a few percent of the overall rate coefficient at $40^{\circ} \mathrm{N} / \mathrm{S}$. The presence of water vapour does not impact significantly on values of $k_{1}$ above the boundary layer.

In Fig. 14 we compare our new parameterisation with preferred parameterisations of the IUPAC and NASA evaluation panels and plot values of $k_{1}$ (IUPAC) / $k_{1}$ (This work) and $k_{1}$ (NASA) / $k_{1}$ (This work) at different altitudes and latitudes. We parameterized $k_{1}$ using the expressions given in this work (Eqn. 5, Table 2) and in the latest evaluations of IUPAC (Iupac, 2021) and NASA (Burkholder et al., 2020). $k_{1}$ (IUPAC) / $k_{1}$ (This work) varies between 0.88 close to the surface to 0.72 at altitudes above $\sim 30 \mathrm{~km}$, whereas $k_{1}$ (NASA) / $k_{1}$ (This work) varies between 0.88 at the surface to $0.92 \mathrm{at} \sim 30 \mathrm{~km}$. Thus, while both evaluations under-predict $k_{1}$ by $\approx 12 \%$ at the surface (partially related to the fact that they do not consider the effects of water-vapour), the NASA parameterisation does well in the lower stratosphere (under-predicting our result by less than 10\%) 
whereas the IUPAC parameters result in a rate coefficient that is too low by almost $30 \%$. At high altitudes the divergent rate coefficients recommended by the evaluation panels reflect the choice of experimental data used to derive the low-pressure limiting rate coefficient and its temperature dependence.

As the reaction between $\mathrm{OH}$ and $\mathrm{SO}_{2}$ ultimately results in the formation of $\mathrm{H}_{2} \mathrm{SO}_{4}$ the atmospheric $\mathrm{H}_{2} \mathrm{SO}_{4} / \mathrm{SO}_{2}$ ratio is sensitive to the rate coefficient $k_{1}$, with an increase in $k_{1}$ resulting in a decrease in $\mathrm{SO}_{2}$ and an increase in $\mathrm{H}_{2} \mathrm{SO}_{4}$, thus amplifying the 385 impact. In Fig. 15 we plot zonally and yearly averaged model values of $\frac{\mathrm{H} 2 \mathrm{SO} 4}{\mathrm{SO} 2}$ (IUPAC)/ $\frac{\mathrm{H} 2 \mathrm{SO} 4}{\mathrm{SO} 2}$ (this work) and $\frac{\mathrm{H} 2 \mathrm{SO} 4}{\mathrm{SO} 2}$ (NASA)/ $\frac{\mathrm{H} 2 \mathrm{SO} 4}{\mathrm{SO} 2}$ (this work). Compared to the parameterization of $k_{1}$ in this work, the IUPAC evaluation returns $\mathrm{H}_{2} \mathrm{SO}_{4} / \mathrm{SO}_{2}$ ratios that are close to 0.9 at the surface but decrease to 0.7 in the lower to mid stratosphere at low latitudes. Again, the NASA parameterisation performs somewhat better, though here we also find an underestimation of the $\mathrm{H}_{2} \mathrm{SO}_{4}$ / $\mathrm{SO}_{2}$ ratio of between 10 and $20 \%$ throughout most of the atmosphere. The impact on the $\mathrm{H}_{2} \mathrm{SO}_{4}$ to $\mathrm{SO}_{2}$ ratio is thus similar to the change in the rate coefficients so that the expected amplification is not observed in the model. This is related to an increase in the sink term of $\mathrm{H}_{2} \mathrm{SO}_{4}$ (via nucleation) which counteracts the increase in its production rate.

The modelling studies indicate that use of IUPAC and NASA parameterizations result in very different values of $k_{1}$ in some parts of the atmosphere and will result in divergent predictions of partitioning of reactive sulphur gases between $\mathrm{SO}_{2}$ and $\mathrm{H}_{2} \mathrm{SO}_{4}$. The present parameterisation, based on precise and accurate temperature dependent measurements in the fall-off regime in $\mathrm{N}_{2}$ does not rely on potentially erroneous data at very low and very high pressures and is expected to lead to more accurate values of $k_{1}$ for modelling the reaction in the Earth's atmosphere both at the surface (where the effect of water-vapour has been considered for the first time) and at the low pressures and temperatures prevalent in the UT-LS region.

\section{Conclusions}

Rate coefficients for the reaction of $\mathrm{SO}_{2}+\mathrm{OH}\left(k_{1}\right)$ in fall-off regime were experimentally determined in a wide range of pressures and temperatures relevant to the atmosphere. More than 100 individual measurements for $k_{1}$ were carried out in $\mathrm{N}_{2}$ and $\mathrm{N}_{2} / \mathrm{H}_{2} \mathrm{O}$ bath gases using pulsed laser photolytic (PLP) generation of $\mathrm{OH}$ coupled to real-time detection of OH via laserinduced fluorescence (LIF). The presence of water-vapour was found to enhance the rate coefficient of the title reaction significantly, indicating that $\mathrm{H}_{2} \mathrm{O}$ is a more efficient 3rd- body collider than $\mathrm{N}_{2}$ or $\mathrm{O}_{2}$ (by a factor of $>5$ ). Based on our comprehensive dataset in the fall-off regime, we derived a new parametrization of the rate coefficient which results in values of $k_{1}$ that are larger than those preferred by the IUPAC and NASA panels, leading to a more rapid removal of $\mathrm{SO}_{2}$ through gas-phase oxidation than previously assumed and thus to an underestimation of the $\mathrm{H}_{2} \mathrm{SO}_{4} / \mathrm{SO}_{2}$ ratio in nearly all regions of the Earth's atmosphere.

410 Acknowledgements. We thank Dr. Mark. Blitz for communicating revised parameters for the University of Leeds dataset on the title reaction. 
Data availability. The rate coefficients measured during this experimental study are listed in the Supplementary information.

Author contributions. The experiments were carried out by WS with assistance from MB and JC. The data analysis was performed by WS. The global modelling was performed by AP. The manuscript was written by WS with assistance from JC and JL.

Competing interests. The authors declare that they have no conflict of interest.

Financial support. The article processing charges for this open access publication were covered by the Max Planck Society.

\section{References}

Amedro, D., Bunkan, A. J., Berasategui, M., and Crowley, J. N.: Kinetics of the $\mathrm{OH}+\mathrm{NO}_{2}$ reaction: rate coefficients (217-333 K, 16-1200 mbar) and fall-off parameters for $\mathrm{N}_{2}$ and $\mathrm{O}_{2}$ bath gases, Atmos. Chem. Phys., 19, 10643-10657, doi:/10.5194/acp-19-10643-2019, 2019.

Amedro, D., Berasategui, M., Bunkan, A. J., Pozzer, A., Lelieveld, J., and Crowley, J. N.: Kinetics of the $\mathrm{OH}_{+} \mathrm{NO}_{2}$ reaction: effect of water vapour and new parameterization for global modelling, Atmos. Chem. Phys., 20, 3091-3105, doi:10.5194/acp-20-3091-2020, 2020.

425 Atkinson, R., Baulch, D. L., Cox, R. A., Crowley, J. N., Hampson, R. F., Hynes, R. G., Jenkin, M. E., Rossi, M. J., and Troe, J.: IUPAC Task Group on Atmospheric Chemical Kinetic Data Evaluation, (http://iupac.pole-ether.fr). Atmos. Chem. Phys., 4, 1461-1738, doi:10.5194/acp-4-1461-2004, 2004.

Badr, O. and Probert, S.: Atmospheric sulphur: trends, sources, sinks and environmental impacts, Applied Energy, 47, 1-67, 1994.

Barnes, I., Bastian, V., Becker, K., Fink, E., and Nelsen, W.: Oxidation of sulphur compounds in the atmosphere: I. Rate constants of OH

430 radical reactions with sulphur dioxide, hydrogen sulphide, aliphatic thiols and thiophenol, J. Atmos. Chem., 4, 445-466, doi:10.1007/BF00053845, 1986.

Beilke, S. and Gravenhorst, G.: Heterogeneous $\mathrm{SO}_{2}$-oxidation in the droplet phase, in: Sulfur in the Atmosphere, Elsevier, 231-239, doi:10.1016/B978-0-08-022932-4.50025-2, 1978.

Bekki, S.: Oxidation of volcanic $\mathrm{SO}_{2}$ : a sink for stratospheric $\mathrm{OH}$ and $\mathrm{H}_{2} \mathrm{O}$, Geophys. Res. Lett., 22, 913-916, doi:10.1029/95GL00534, 1995.

Blitz, M. A., Hughes, K. J., and Pilling, M. J.: Determination of the high-pressure limiting rate coefficient and the enthalpy of reaction for $\mathrm{OH}+\mathrm{SO}_{2}$, J. Phys. Chem. A, 107, 1971-1978, 2003.

Blitz, M. A., Salter, R. J., Heard, D. E., and Seakins, P. W.: An experimental study of the kinetics of OH/OD (v=1, 2, 3)+ SO 2 : the limiting high-pressure rate coefficients as a function of temperature, The Journal of Physical Chemistry A, 121, 3175-3183, 440 doi:10.1021/acs.jpca.7b01294, 2017a.

Blitz, M. A., Salter, R. J., Heard, D. E., and Seakins, P. W.: An Experimental and Master Equation Study of the Kinetics of OH/OD+ SO2: The Limiting High-Pressure Rate Coefficients, The Journal of Physical Chemistry A, 121, 3184-3191, doi:10.1021/acs.jpca.7b01295, 2017b.

Brimblecombe, P.: The global sulfur cycle, in: Treatise on Geochemistry: Second Edition, Elsevier Inc., 559-591, doi:10.1016/B978-0-08095975-7.00814-7, 2013.

445 Brown, K. A.: Sulphur in the environment: a review, Environmental Pollution Series B, Chemical and Physical, 3, 47-80, doi:10.1016/0143148X(82)90042-8, 1982.

Burke, M. P. and Song, R.: Evaluating mixture rules for multi-component pressure dependence: $\mathrm{H}^{+\mathrm{O}_{2}}(+\mathrm{M})=\mathrm{HO}_{2}(+\mathrm{M})$, Proceedings of the Combustion Institute, 36, 245-253, https://doi.org/10.1016/j.proci.2016.06.068, 2017. 
Burkholder, J., Sander, S., Abbatt, J., Barker, J., Cappa, C., Crounse, J., Dibble, T., Huie, R., Kolb, C., and Kurylo, M.: Chemical kinetics and photochemical data for use in atmospheric studies; evaluation number 19, Jet Propulsion Laboratory, National Aeronautics and Space Administration, 2020.

Cantrell, C. A., Zimmer, A., and Tyndall, G. S.: Absorption cross sections for water vapor from 183 to 193 nm, Geophys. Res. Lett., 24, 2195-2198, 1997.

Castleman Jr, A. and Tang, I.: Kinetics of the association reaction of $\mathrm{SO}_{2}$ with the hydroxyl radical, J. Photochem., 6, 349-354, doi:10.1016/0047-2670(76)85073-3, 1976.

Cox, R.: Photochemical oxidation of atmospheric sulphur dioxide, Philosophical Transactions of the Royal Society of London. Series A, Mathematical and Physical Sciences, 290, 543-550, doi:10.1098/rsta.1979.0013, 1979.

Cox, R. and Sheppard, D.: Reactions of OH radicals with gaseous sulphur compounds, Nature, 284, 330-331, doi:10.1038/284330a0, 1980.

Davis, D., Ravishankara, A., and Fischer, S.: $\mathrm{SO}_{2}$ oxidation via the hydroxyl radical: atmospheric fate of HSOx radicals, Geophys. Res.

Lett., 6, 113-116, doi:10.1029/GL006i002p00113, 1979.

Deckert, R., Jockel, P., Grewe, V., Gottschaldt, K. D., and Hoor, P.: A quasi chemistry-transport model mode for EMAC, Geoscientific Model Development, 4, 195-206, 2011.

Dulitz, K., Amedro, D., Dillon, T. J., Pozzer, A., and Crowley, J. N.: Temperature-(208-318 K) and pressure-(18-696 Torr) dependent rate coefficients for the reaction between $\mathrm{OH}$ and $\mathrm{HNO}_{3}$, Atmos. Chem. Phys., 18, 2381-2394, doi:10.5194/acp-18-2381-2018, 2018.

465 Feichter, J., Kjellström, E., Rodhe, H., Dentener, F., Lelieveldi, J., and Roelofs, G.-J.: Simulation of the tropospheric sulfur cycle in a global climate model, Atmos. Env., 30, 1693-1707, doi:10.1016/1352-2310(95)00394-0, 1996.

Fulle, D., F. Hamann, H., and Hippler, H.: The pressure and temperature dependence of the recombination reaction $\mathrm{HO}+\mathrm{SO}_{2}+\mathrm{M} \rightarrow \mathrm{HOSO}_{2}+\mathrm{M}$, Phys. Chem. Chem. Phys., 1, 2695-2702, doi:10.1039/A901596E, 1999.

Heckendorn, P., Weisenstein, D., Fueglistaler, S., Luo, B. P., Rozanov, E., Schraner, M., Thomason, L. W., and Peter, T.: The impact of geoengineering aerosols on stratospheric temperature and ozone, Environ. Res. Lett., 4, 045108, doi:10.1088/1748-9326/4/4/045108, 2009.

Huang, H.-L. and Chao, W.: Kinetics of a Criegee intermediate that would survive high humidity and may oxidize atmospheric $\mathrm{SO}_{2}$, Proceedings of the National Academy of Sciences, 112, 10857-10862, doi:10.1073/pnas.1513149112, 2015.

IUPAC Task Group on Atmospheric Chemical Kinetic Data Evaluation, (Ammann, M., Cox, R.A., Crowley, J.N., Herrmann, H., Jenkin, M.E., McNeill, V.F., Mellouki, A., Rossi, M. J., Troe, J. and Wallington, T. J.). Last access Sept. 2021: http://iupac.pole-ether.fr/index.html.

475 Izumi, K., Mizuochi, M., Yoshioka, M., Murano, K., and Fukuyama, T.: Redetermination of the rate constant for the reaction of hydroxyl radicals with sulfur dioxide, Env. Sci. Tech., 18, 116-118, doi:10.1021/es00120a014, 1984.

Jeuken, A. B. M., Siegmund, P. C., Heijboer, L. C., Feichter, J., and Bengtsson, L.: On the potential of assimilating meteorological analyses in a global climate model for the purpose of model validation, J. Geophys. Res. -Atmos., 101, 16939-16950, 1996.

Jöckel, P., Kerkweg, A., Pozzer, A., Sander, R., Tost, H., Riede, H., Baumgaertner, A., Gromov, S., and Kern, B.: Development cycle 2 of the Modular Earth Submodel System (MESSy2), Geoscientific Model Development, 3, 717-752, 2010.

Jöckel, P., Tost, H., Pozzer, A., Bruhl, C., Buchholz, J., Ganzeveld, L., Hoor, P., Kerkweg, A., Lawrence, M. G., Sander, R., Steil, B., Stiller, G., Tanarhte, M., Taraborrelli, D., Van Aardenne, J., and Lelieveld, J.: The atmospheric chemistry general circulation model ECHAM5/MESSy1: consistent simulation of ozone from the surface to the mesosphere, Atmos. Chem. Phys., 6, 5067-5104, 2006.

Kulmala, M., Laaksonen, A., and Pirjola, L.: Parameterizations for sulfuric acid/water nucleation rates, Journal of Geophysical Research: 485 Atmospheres, 103, 8301-8307, doi:10.1029/97JD03718, 1998.

Lee, Y. Y., Kao, W. C., and Lee, Y. P.: Kinetics of the reaction hydroxyl + sulfur dioxide in helium, nitrogen, and oxygen at low pressure, J. Phys. Chem., 94, 4535-4540, doi:10.1021/j100374a035, 1990.

Lelieveld, J. and Heintzenberg, J.: Sulfate cooling effect on climate through in-cloud oxidation of anthropogenic SO 2 , Science, 258, 117120, doi:10.1126/science.258.5079.117, 1992. 

Philosophical Transactions of the Royal Society of London. Series B: Biological Sciences, 352, 149-158, doi:10.1098/rstb.1997.0010, 1997.

Leu, M. T.: Rate constants for the reaction of hydroxyl with sulfur dioxide at low pressure, The Journal of Physical Chemistry, 86, 45584562, doi:10.1021/es00120a014, 1982.

Liu, T., Clegg, S. L., and Abbatt, J. P.: Fast oxidation of sulfur dioxide by hydrogen peroxide in deliquesced aerosol particles, Proceedings of the National Academy of Sciences, 117, 1354-1359, doi:10.1073/pnas.1916401117, 2020.

Manatt, S. L. and Lane, A. L.: A compilation of the absorption cross-sections of $\mathrm{SO}_{2}$ from 106 to 403 nm, Journal of Quantitative Spectroscopy and Radiative Transfer, 50, 267-276, doi:10.1016/0022-4073(93)90077-U, 1993.

Martin, D., Jourdain, J., and Le Bras, G.: Discharge flow measurements of the rate constants for the reaction $\mathrm{OH}+\mathrm{SO}_{2}+\mathrm{He}$ and $\mathrm{HOSO}_{2}+\mathrm{O}_{2}$ in relation with the atmospheric oxidation of sulfur dioxide, The Journal of Physical Chemistry, 90, 4143-4147, doi:10.1021/j100408a061, 1986.

Mauldin Iii, R., Berndt, T., Sipilä, M., Paasonen, P., Petäjä, T., Kim, S., Kurtén, T., Stratmann, F., Kerminen, V.-M., and Kulmala, M.: A new atmospherically relevant oxidant of sulphur dioxide, Nature, 488, 193-196, doi:10.1038/nature11278, 2012.

Paraskevopoulos, G., Singleton, D. L., and Irwin, R. S.: Rates of OH radical reactions. The reaction $\mathrm{OH}+\mathrm{SO}_{2}+\mathrm{N}_{2}$, Chem. Phys. Lett., 100, 83-87, doi:10.1016/0009-2614(83)87267-4, 1983.

505 Pozzer, A., de Meij, A., Pringle, K. J., Tost, H., Doering, U. M., van Aardenne, J., and Lelieveld, J.: Distributions and regional budgets of aerosols and their precursors simulated with the EMAC chemistry-climate model, Atmos. Chem. Phys., 12, 961-987, 2012a.

Pozzer, A., Zimmermann, P., Doering, U. M., van Aardenne, J., Tost, H., Dentener, F., Janssens-Maenhout, G., and Lelieveld, J.: Effects of business-as-usual anthropogenic emissions on air quality, Atmos. Chem. Phys., 12, 6915-6937, 10.5194/acp-12-6915-2012, 2012b.

Reifenberg, S. F., Martin, A., Kohl, M., Hamryszczak, Z., Tadic, I., Röder, L., Crowley, D. J., Fischer, H., Kaiser, K., Schneider, J., Dörich, R., Crowley, J. N., Tomsche, L., Marsing, A., Voigt, C., Zahn, A., Pöhlker, C., Holanda, B., Krüger, O. O., Pöschl, U., Pöhlker, M., Jöckel, P., Dorf, M., Schumann, U., Williams, J., Curtius, J., Harder, H., Schlager, H., Lelieveld, J., and Pozzer, A.: Impact of reduced emissions on direct and indirect aerosol radiative forcing during COVID-19 lockdown in Europe, Atmos. Chem. Phys. Discuss., 2021, 1-23, 10.5194/acp-2021-1005, 2021.

Roeckner, E., Brokopf, R., Esch, M., Giorgetta, M., Hagemann, S., Kornblueh, L., Manzini, E., Schlese, U., and Schulzweida, U.: Sensitivity of simulated climate to horizontal and vertical resolution in the ECHAM5 atmosphere model, Journal of Climate, 19, 3771-3791, 2006.

Rollins, A. W., Thornberry, T. D., Ciciora, S. J., McLaughlin, R. J., Watts, L. A., Hanisco, T. F., Baumann, E., Giorgetta, F. R., Bui, T. V., and Fahey, D. W.: A laser-induced fluorescence instrument for aircraft measurements of sulfur dioxide in the upper troposphere and lower stratosphere, Atmos. Meas. Tech., 9, 4601-4613, doi:10.5194/amt-9-4601-2016, 2016.

Rufus, J., Stark, G., Smith, P. L., Pickering, J., and Thorne, A.: High-resolution photoabsorption cross section measurements of $\mathrm{SO}_{2}$, 2: 220 to $325 \mathrm{~nm}$ at $295 \mathrm{~K}$, Journal of Geophysical Research: Planets, 108, doi:10.1029/2002JE001931, 2003.

Saltzman, E., Brass, G., and Price, D.: The mechanism of sulfate aerosol formation: Chemical and sulfur isotopic evidence, Geophys. Res. Lett., 10, 513-516, doi:10.1029/GL010i007p00513, 1983.

Schiffman, A., Nelson Jr, D., and Nesbitt, D. J.: Quantum yields for $\mathrm{OH}$ production from 193 and 248 nm photolysis of $\mathrm{HNO}_{3}$ and $\mathrm{H}_{2} \mathrm{O}_{2}$, The Journal of chemical physics, 98, 6935-6946, doi:10.1063/1.464735, 1993.

525 Sipilä, M., Berndt, T., Petäjä, T., Brus, D., Vanhanen, J., Stratmann, F., Patokoski, J., Mauldin, R. L., Hyvärinen, A.-P., and Lihavainen, H.: The role of sulfuric acid in atmospheric nucleation, Science, 327, 1243-1246, doi:10.1126/science.1180315, 2010.

Stark, G., Smith, P. L., Rufus, J., Thorne, A., Pickering, J., and Cox, G.: High-resolution photoabsorption cross-section measurements of SO2 at 295 K between 198 and 220 nm, Journal of Geophysical Research: Planets, 104, 16585-16590, doi:10.1029/2002JE001931, 1999.

Stevenson, D., Johnson, C., Collins, W., and Derwent, R.: The tropospheric sulphur cycle and the role of volcanic $\mathrm{SO}_{2}$, Geological Society, London, Special Publications, 213, 295-305, doi:10.1144/GSL.SP.2003.213.01.18, 2003.

Stutz, J., Kim, E., Platt, U., Bruno, P., Perrino, C., and Febo, A.: UV-visible absorption cross sections of nitrous acid, Journal of Geophysical Research: Atmospheres, 105, 14585-14592, doi:10.1016/S1352-2310(99)00322-2, 2000. 
https://doi.org/10.5194/acp-2021-1074

Preprint. Discussion started: 9 February 2022

(C) Author(s) 2022. CC BY 4.0 License.

Troe, J.: Theory of thermal unimolecular reactions in the fall-off range. I. Strong collision rate constants, Berichte der Bunsengesellschaft für physikalische Chemie, 87, 161-169, 1983.

535 Troe, J.: Toward a Quantitative Analysis of Association Reactions in the Atmosphere, Chem. Rev., 103, 4565-4576, 10.1021/cr020514b, 2003.

Troe, J. and Ushakov, V. G.: Representation of "broad" falloff curves for dissociation and recombination reactions, Zeitschrift für Physikalische Chemie, 228, 1-10, doi:10.1515/zpch-2014-04, 2014.

Vaghjiani, G. L. and Ravishankara, A.: Absorption cross sections of $\mathrm{CH}_{3} \mathrm{OOH}, \mathrm{H}_{2} \mathrm{O}_{2}$, and $\mathrm{D}_{2} \mathrm{O}_{2}$ vapors between 210 and $365 \mathrm{~nm}$ at $297 \mathrm{~K}$, Journal of Geophysical Research: Atmospheres, 94, 3487-3492, doi:10.1029/JD094iD03p03487, 1989.

Vehkamäki, H., Kulmala, M., Napari, I., Lehtinen, K. E., Timmreck, C., Noppel, M., and Laaksonen, A.: An improved parameterization for sulfuric acid-water nucleation rates for tropospheric and stratospheric conditions, Journal of Geophysical Research: Atmospheres, 107, AAC 3-1-AAC 3-10, doi:10.1029/2002JD002184, 2002.

Weisenstein, D. K., Ko, M. K., Sze, N. D., and Rodriguez, J. M.: Potential impact of $\mathrm{SO}_{2}$ emissions from stratospheric aircraft on ozone, 545 Geophys. Res. Lett., 23, 161-164, doi:10.1029/95GL03781, 1996.

Wine, P., Thompson, R., Ravishankara, A., Semmes, D., Gump, C., Torabi, A., and Nicovich, J.: Kinetics of the reaction $\mathrm{OH}^{+} \mathrm{SO}_{2}+\mathrm{M}_{\text {. }}$ fwdarw. $\mathrm{HOSO}_{2}+\mathrm{M}$. Temperature and pressure dependence in the fall-off region, The Journal of Physical Chemistry, 88, 2095-2104, doi:10.1021/j150654a031, 1984.

Wollenhaupt, M., Carl, S., Horowitz, A., and Crowley, J.: Rate coefficients for reaction of OH with acetone between 202 and 395 K, The Journal of Physical Chemistry A, 104, 2695-2705, doi:10.1021/jp993738f, 2000.

Yan, Y. Y., Lin, J. T., Pozzer, A., Kong, S. F., and Lelieveld, J.: Trend reversal from high-to-low and from rural-to-urban ozone concentrations over Europe, Atmos. Env., 213, 25-36, 10.1016/j.atmosenv.2019.05.067, 2019. 
https://doi.org/10.5194/acp-2021-1074

Preprint. Discussion started: 9 February 2022

(C) Author(s) 2022. CC BY 4.0 License.

555 Table 1. Temperature and pressure-dependent measurements of $\boldsymbol{k}_{\mathbf{1}}$

\begin{tabular}{|c|c|c|c|c|c|}
\hline Reference & Technique & OH generation & $\begin{array}{l}{\left[\mathrm{SO}_{2}\right]} \\
\text { measurement }\end{array}$ & $\begin{array}{l}\text { Bath gas } \\
\text { (Temp / K) }\end{array}$ & $\begin{array}{l}\text { Pressure } \\
\text { (Torr) }\end{array}$ \\
\hline Leu (1982) & DF-RF & $\mathrm{NO}_{2}+\mathrm{H}$ & manometric & $\begin{array}{l}\mathrm{He}(261-414) \\
\mathrm{Ar}(298) \\
\mathrm{N}_{2}(298) \\
\mathrm{O}_{2}(298) \\
\mathrm{CO}_{2}(298)\end{array}$ & $<10$ \\
\hline (Paraskevopoulos et al., 1983) & FP-RA & $\mathrm{N}_{2} \mathrm{O} / \mathrm{H}_{2}+h v$ & manometric & $\mathrm{N}_{2}(297)$ & $50-760$ \\
\hline (Wine et al., 1984) & FP-RF & $\mathrm{H}_{2} \mathrm{O}+h v$ & $\begin{array}{l}\text { optical } \\
\text { absorption }\end{array}$ & $\begin{array}{l}\mathrm{He}(300 \mathrm{~K}) \\
\mathrm{Ar}(260,300, \\
360 \text { and } 420 \mathrm{~K}) \\
\mathrm{N}_{2}(300 \mathrm{~K}) \\
\mathrm{SiF}_{6}(260,300, \\
360 \text { and } 420 \mathrm{~K})\end{array}$ & $13-696$ \\
\hline (Martin et al., 1986) & $\begin{array}{l}\text { DF-EPR } \\
\text { DF-MS }\end{array}$ & $\mathrm{NO}_{2}+\mathrm{H}$ & manometric & He (RT) & $1-6$ \\
\hline (Lee et al., 1990) & DF-RF & $\mathrm{NO}_{2}+\mathrm{H}$ & manometric & $\begin{array}{l}\mathrm{He}(280-413) \\
\mathrm{N}_{2}(298) \\
\mathrm{O}_{2}(298)\end{array}$ & $<6$ \\
\hline (Fulle et al., 1999) & FP-LIF & $\mathrm{O}_{3} / \mathrm{CH}_{4}+h v$ & manometric & Не (220-400) & $760-72000$ \\
\hline (Blitz et al., 2003) & LP-LIF & $\begin{array}{l}\mathrm{CHBr}_{3} \\
\mathrm{H}_{2} \mathrm{O}_{2}+h v\end{array}$ & manometric & He (295-673) & $100-200$ \\
\hline (Blitz et al., 2017a) & LP-LIF & $\begin{array}{l}\mathrm{SO}_{2}+\mathrm{H}_{2}+h v \\
\left(\mathrm{CH}_{3}\right)_{3} \mathrm{COOH}+\mathrm{hv}\end{array}$ & manometric & He (295) & $25-303$ \\
\hline This work & LP-LIF & $\begin{array}{l}\mathrm{H}_{2} \mathrm{O}_{2}+h v \\
\mathrm{HNO}_{3}+h v \\
\mathrm{HONO}+h v\end{array}$ & $\begin{array}{l}\text { optical } \\
\text { absorption }\end{array}$ & $\mathrm{N}_{2}(220-333)$ & $14-742$ \\
\hline
\end{tabular}

Notes: DF-RF = discharge flow- resonance fluorescence, FP-RA = flash photolysis- resonance absorption, FP-RF $=$ flash photolysisresonance fluorescence, DF-EPR-MS = discharge flow-electric paramagnetic resonance / mass spectrometry, FP-LIF = flash photolysislaser induced fluorescence, LP-LIF = laser flash photolysis-laser-induced fluorescence. RT = room temperature. 
https://doi.org/10.5194/acp-2021-1074

Preprint. Discussion started: 9 February 2022

(C) Author(s) 2022. CC BY 4.0 License.

560 Table 2. Parameterisation of $\boldsymbol{k}_{1}$ in $\mathbf{N}_{2}$

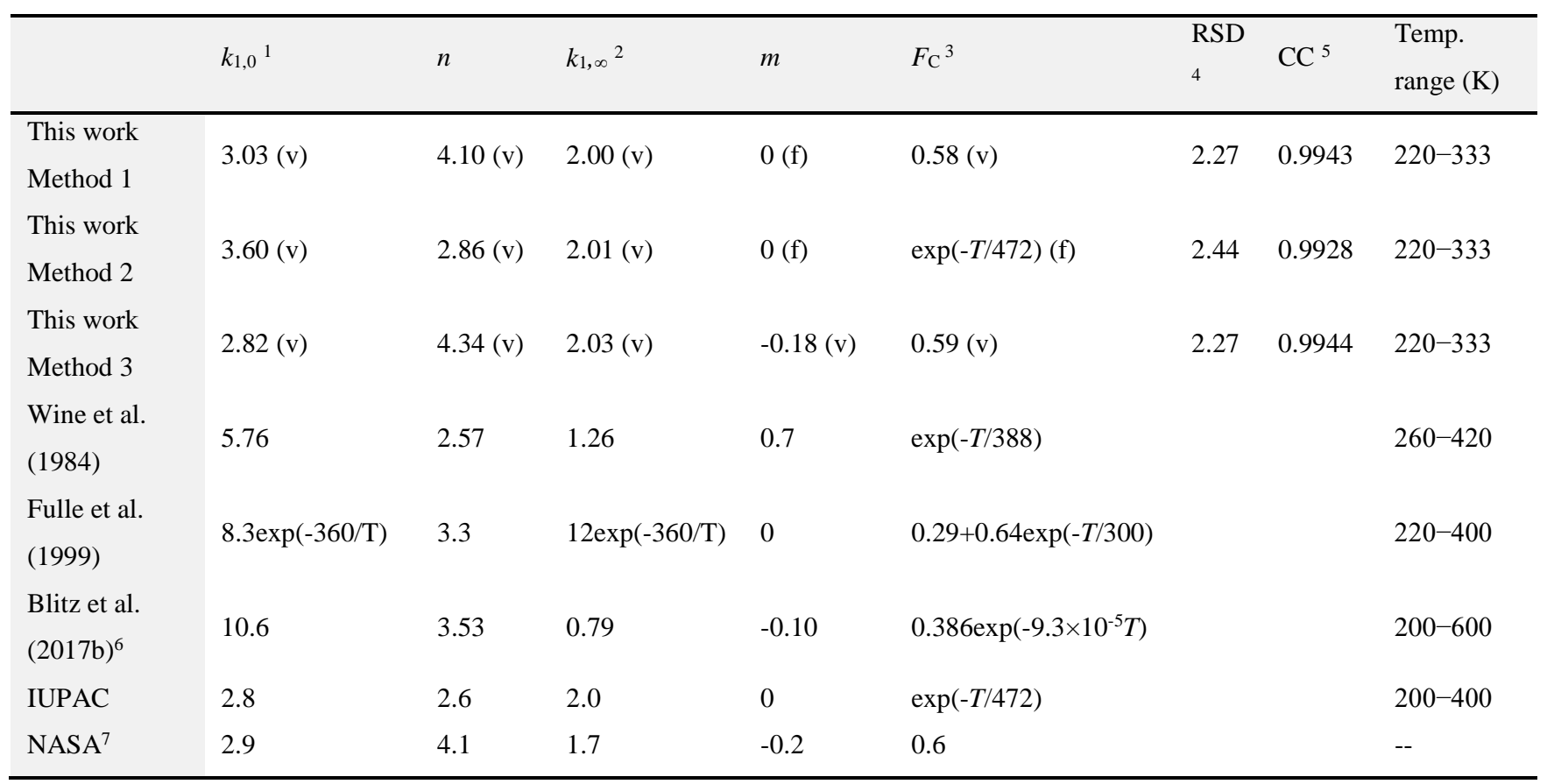

Notes: ${ }^{1}$ Units of $10^{-31} \mathrm{~cm}^{6}$ molecule ${ }^{-2} \mathrm{~s}^{-1},{ }^{2}$ Units of $10^{-12} \mathrm{~cm}^{3}$ molecule ${ }^{-1} \mathrm{~s}^{-1},{ }^{3}$ Temperature (T) in K. ${ }^{4} \mathrm{RSD}$ (residual standard deviation) for the fitting is defined as $\sqrt{\sum\left(k_{1}-k_{1 p}\right)^{2} / N-2}, k_{1}$ and $k_{1 p}$ are the measured and the fitted rate coefficients and $\mathrm{N}$ is the total number of the data points, with the unit of $10^{-14} \mathrm{~cm}^{3}$ molecule $\mathrm{e}^{-1} \mathrm{~s}^{-1} \cdot \mathrm{v}=$ allowed to vary during fitting, $\mathrm{f}=$ fixed during fitting. ${ }^{5} \mathrm{CC}$ is the correlation coefficient $\left(\mathrm{R}^{2}\right) .{ }^{6}$ The parameters, which are different from those given in Blitz et al. (2017b) are from a personal communication with

565 Mark Blitz. The parameterization is based on the modified fall-off parameterisation in Troe and Ushakov (2014), details are given in the Supplementary Information. ${ }^{7}$ The simplified form of the Troe expression for termolecular reactions used by NASA can be found in the Supplementary Information. 
https://doi.org/10.5194/acp-2021-1074

Preprint. Discussion started: 9 February 2022

(C) Author(s) 2022. CC BY 4.0 License.

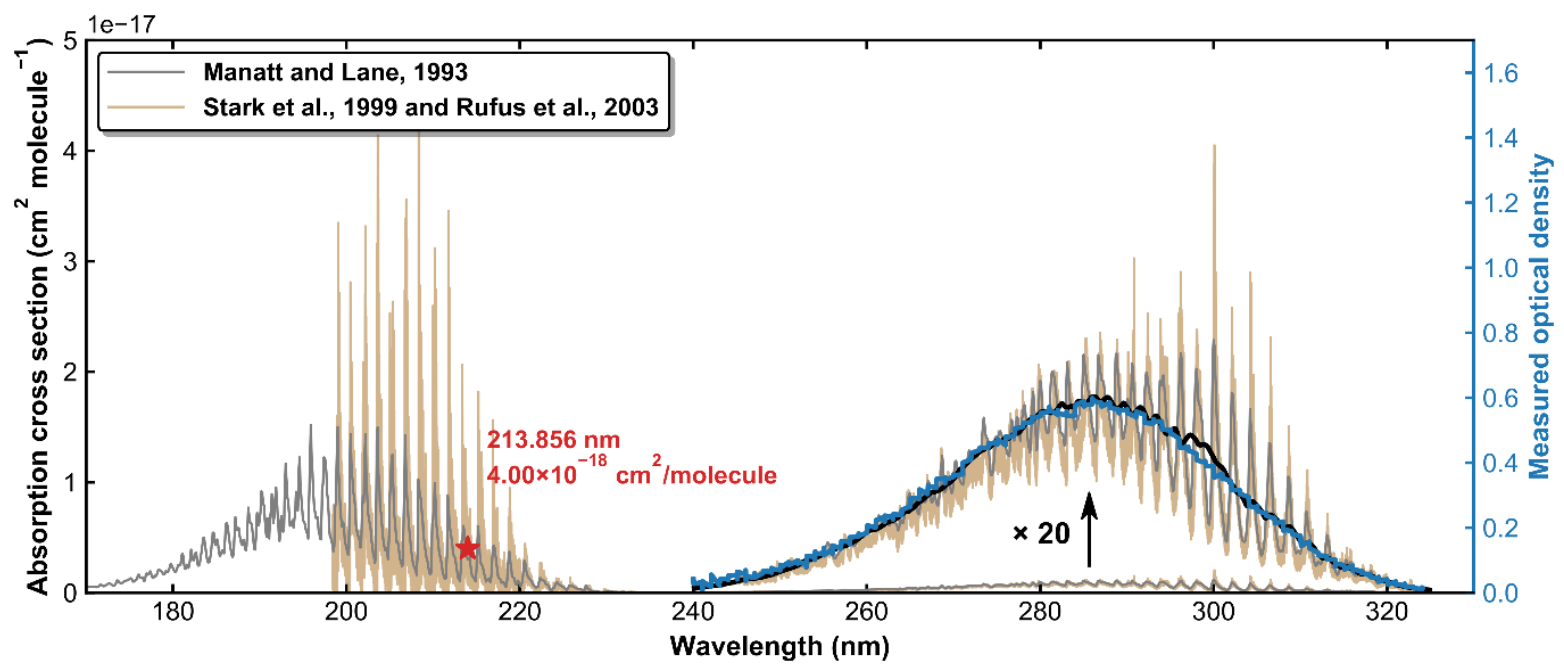

Figure 1. $\mathrm{SO}_{2}$ absorption spectra reported by Manatt and Lane (1993) and Stark and co-workers (Stark et al., 1999; Rufus et al., 2003). The black line is the result of degrading the resolution in the $240-325 \mathrm{~nm}$ region to that of our our optical density measurements (blue line). 
https://doi.org/10.5194/acp-2021-1074

Preprint. Discussion started: 9 February 2022

(C) Author(s) 2022. CC BY 4.0 License.

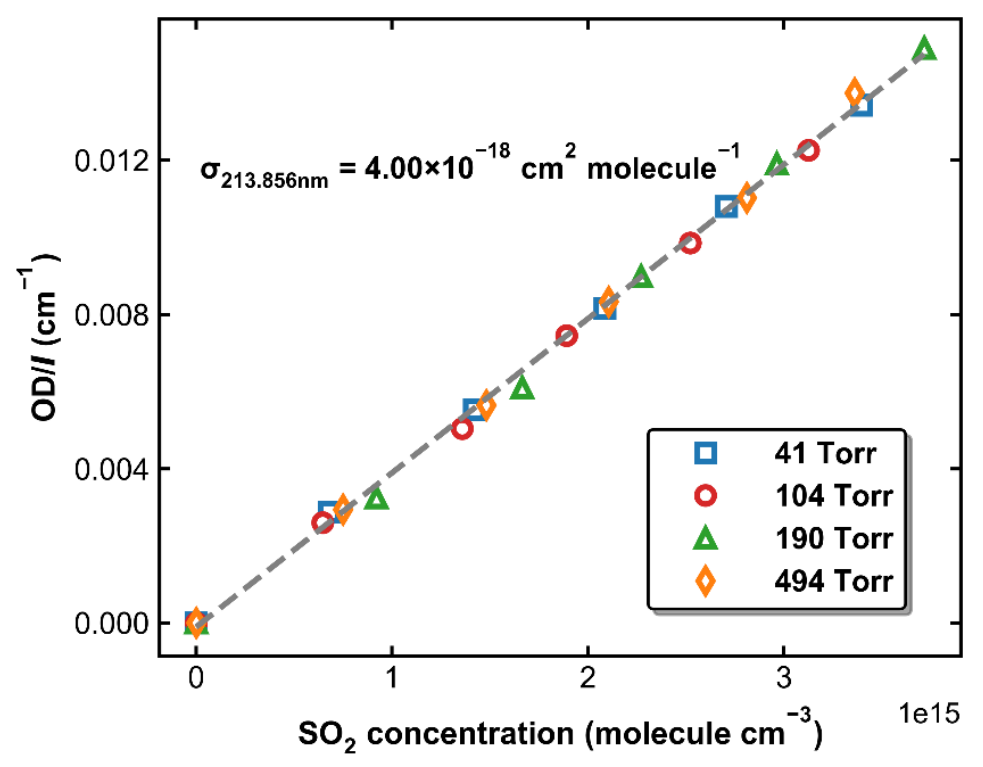

Figure 2. Normalized optical density in the $213.86 \mathrm{~nm}$ absorption cell as a function of $\mathrm{SO}_{2}$ concentration measured using the multi-pass absorption cell. The experiments were performed at $298 \mathrm{~K}$ and pressures of 41, 104, 190 and 494 Torr. The grey dashed line is the linear regression, for which the slope is the effective cross section of $\mathrm{SO}_{2}$ at $213.86 \mathrm{~nm}$. 
https://doi.org/10.5194/acp-2021-1074

Preprint. Discussion started: 9 February 2022

(C) Author(s) 2022. CC BY 4.0 License.

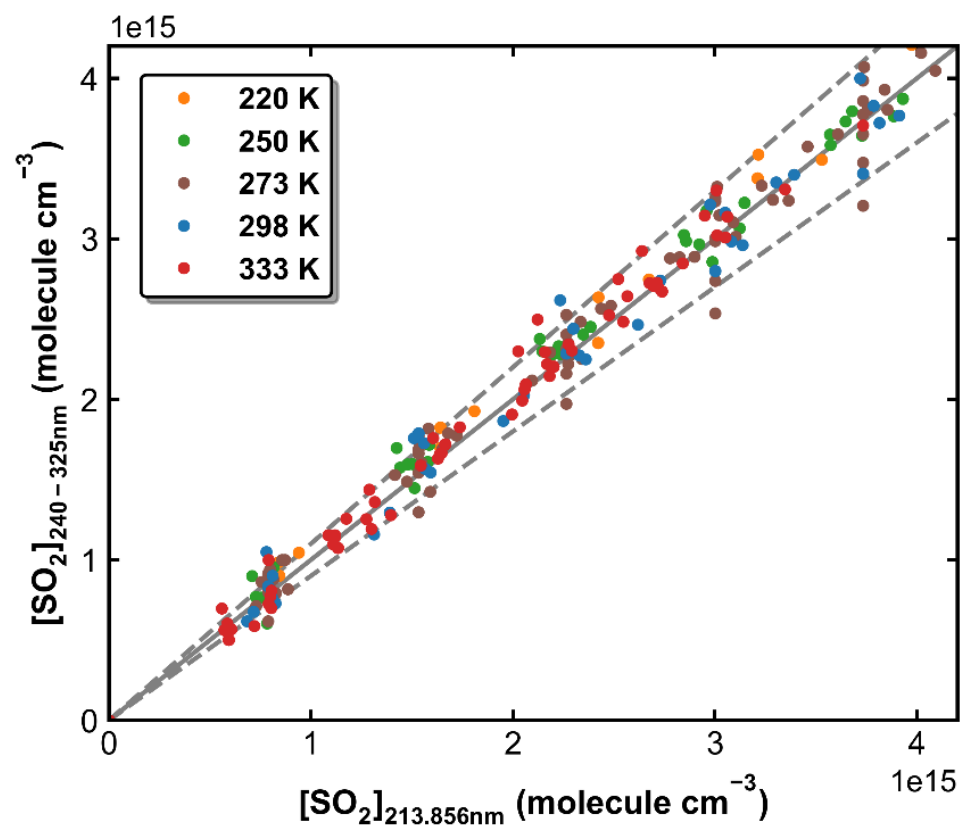

580 Figure 3. $\mathrm{SO}_{2}$ concentrations measured in the experiments at different temperatures using the multi-pass absorption cell upstream of the reactor ( $y$ axis) and the $213.86 \mathrm{~nm}$ absorption cell downstream of the reactor ( $x$ axis). The solid line represents $y=x$, and the dashed lines are $y=1.1 x$ and $y=0.9 x$. 
https://doi.org/10.5194/acp-2021-1074

Preprint. Discussion started: 9 February 2022

(C) Author(s) 2022. CC BY 4.0 License.

(c) (i)
Atmospheric

Chemistry

and Physics

Discussions

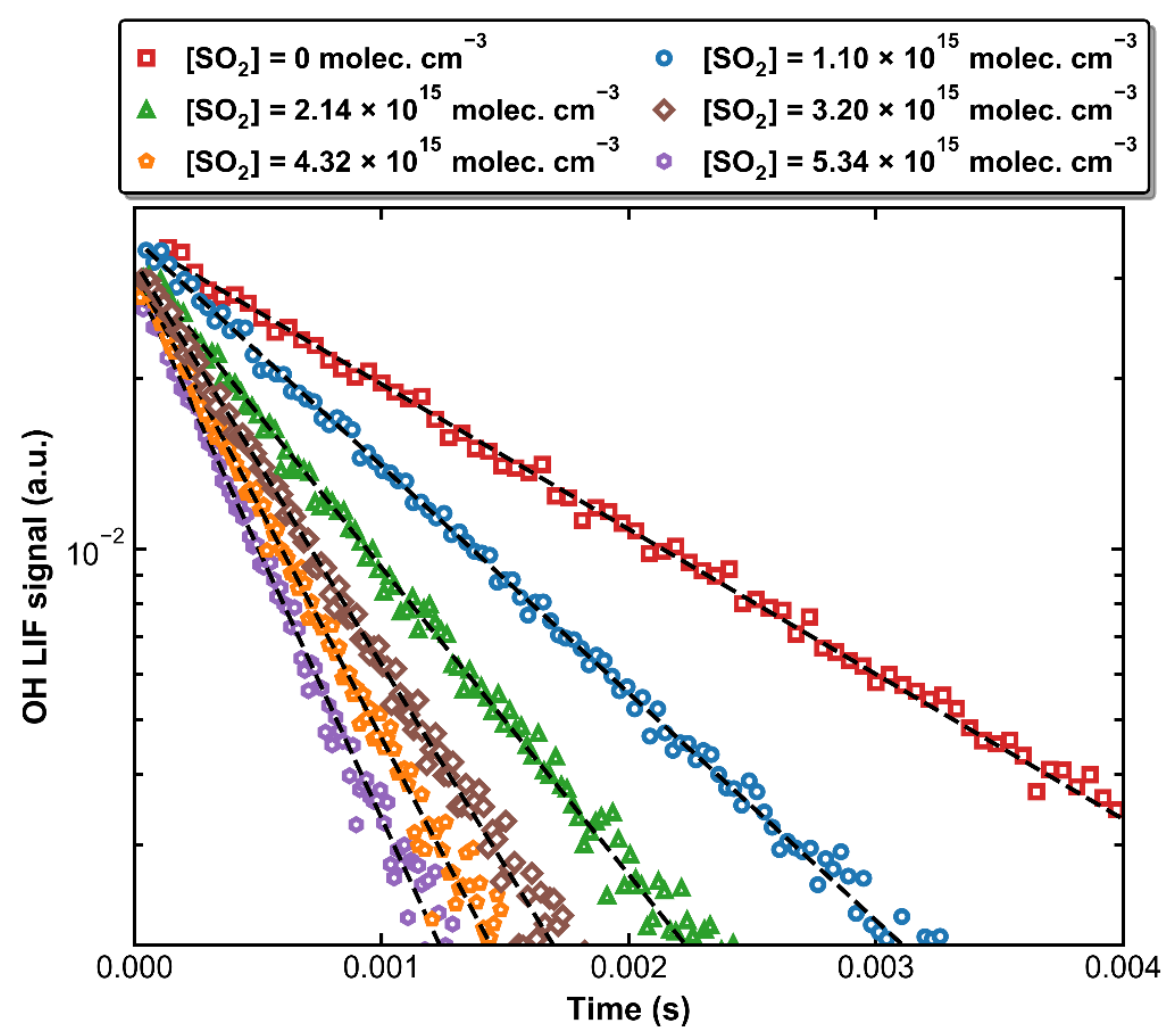

585 Figure 4. Exponential decay of $\mathrm{OH}$ at $298 \mathrm{~K}$ and 59.9 Torr $\left(\mathrm{N}_{2}\right.$ bath gas) in the presence of six different $\mathrm{SO}_{2}$ concentrations. OH was generated by the photolysis of $\mathrm{H}_{2} \mathrm{O}_{2}$ at $248 \mathrm{~nm}$ The black dashed lines are fits using Eqn. (1). 
https://doi.org/10.5194/acp-2021-1074

Preprint. Discussion started: 9 February 2022

(c) Author(s) 2022. CC BY 4.0 License.

(c) (i)
Atmospheric

Chemistry

and Physics

Discussions

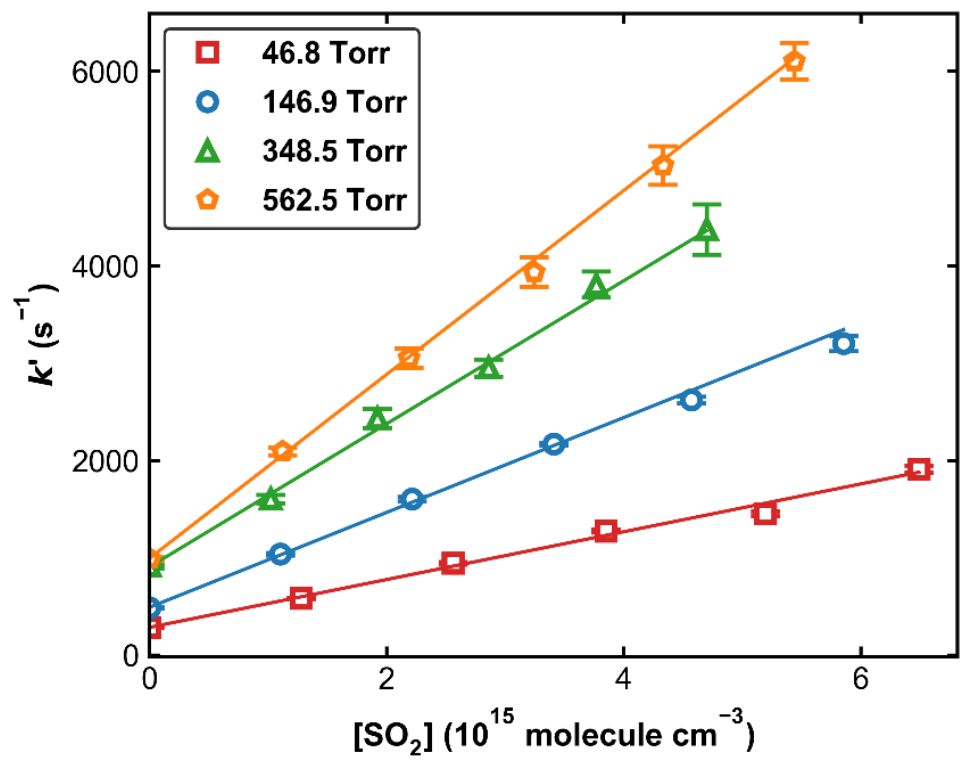

Figure 5. Pseudo-first-order rate coefficients $\left(k^{\prime}\right)$ as a function of $\mathrm{SO}_{2}$ concentration ([SO 2$\left.]\right)$ at four different pressures at $298 \mathrm{~K}$. Error bars represent $2 \sigma$ statistical uncertainties. The lines are weighted linear regressions. 
https://doi.org/10.5194/acp-2021-1074

Preprint. Discussion started: 9 February 2022

(c) Author(s) 2022. CC BY 4.0 License.

(c) (i)
Atmospheric

Chemistry

and Physics

Discussions

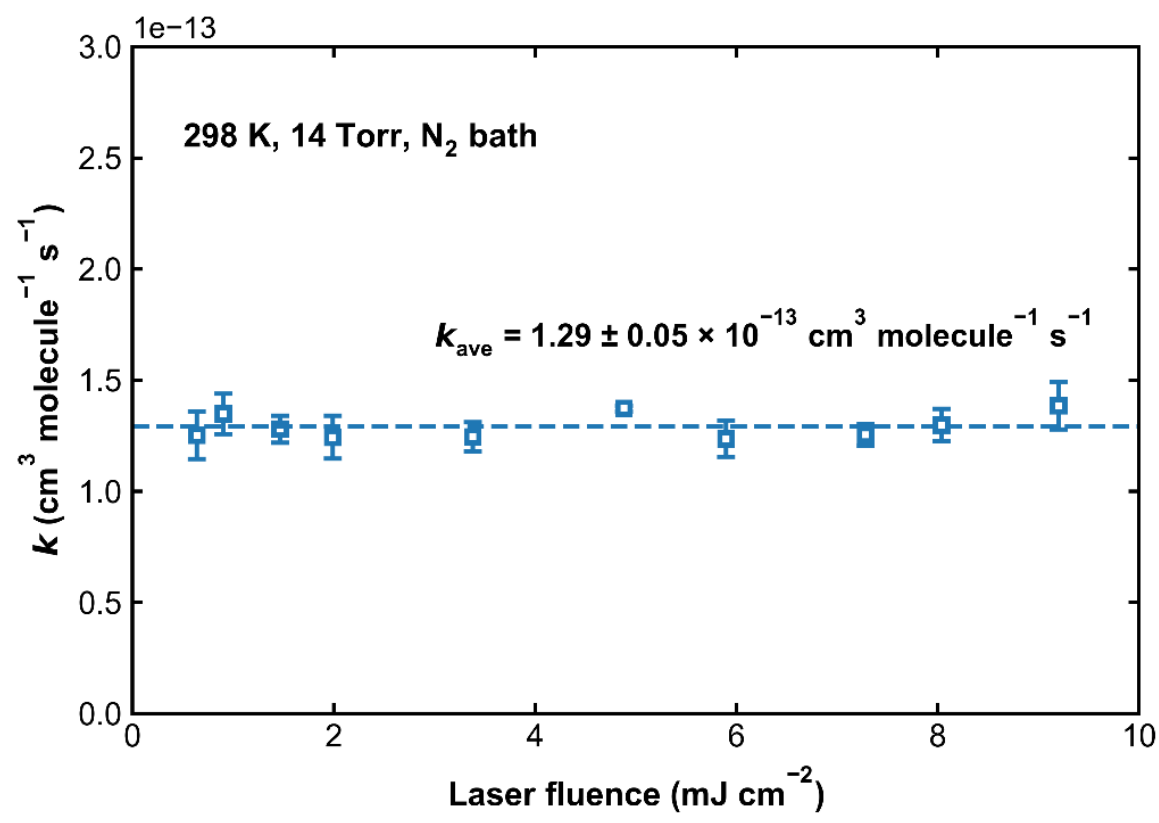

Figure 6. Values of $k_{1}$ measured at $298 \mathrm{~K}$ and in 14 Torr of $\mathrm{N}_{2}$ bath gas. The $248 \mathrm{~nm}$ laser fluence was varied by a factor of $\sim 14$. The dashed line represents the average rate coefficient. 
https://doi.org/10.5194/acp-2021-1074

Preprint. Discussion started: 9 February 2022

(C) Author(s) 2022. CC BY 4.0 License.

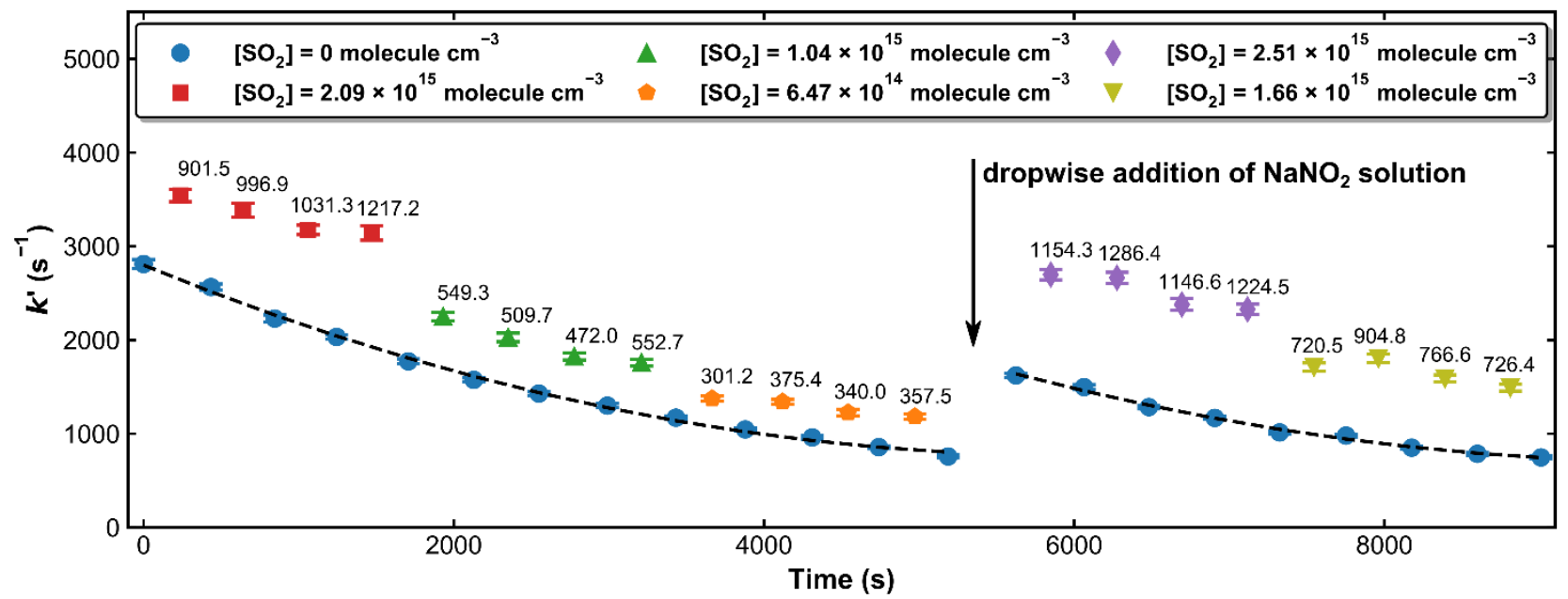

Figure 7. Pseudo-first-order rate coefficients ( $\left.k^{\prime}\right)$ at 193.2 Torr and $298 \mathrm{~K}$ whereby OH was generated by the 351 nm photolysis of HONO. The time dependent $\mathrm{OH}$ decay constants in the absence of $\mathrm{SO}_{2}$ (blue symbols) were fit to a second-degree polynomial (black dashed lines). The number on the top of each data point when $\mathrm{SO}_{2}$ is present (red, green, orange, purple and olive coloured symbols), represents the difference in $k^{\prime}$ to that obtained (by interpolation) in the absence of $\mathrm{SO}_{2}$. A few drops of the $\mathrm{NaNO}_{2}$ solution was re-added after about 90 minutes to maintain $\mathrm{OH}$ levels and thus a good signal-to-noise ratio. 
https://doi.org/10.5194/acp-2021-1074

Preprint. Discussion started: 9 February 2022

(c) Author(s) 2022. CC BY 4.0 License.

(c) (i)
Atmospheric

Chemistry

and Physics

Discussions

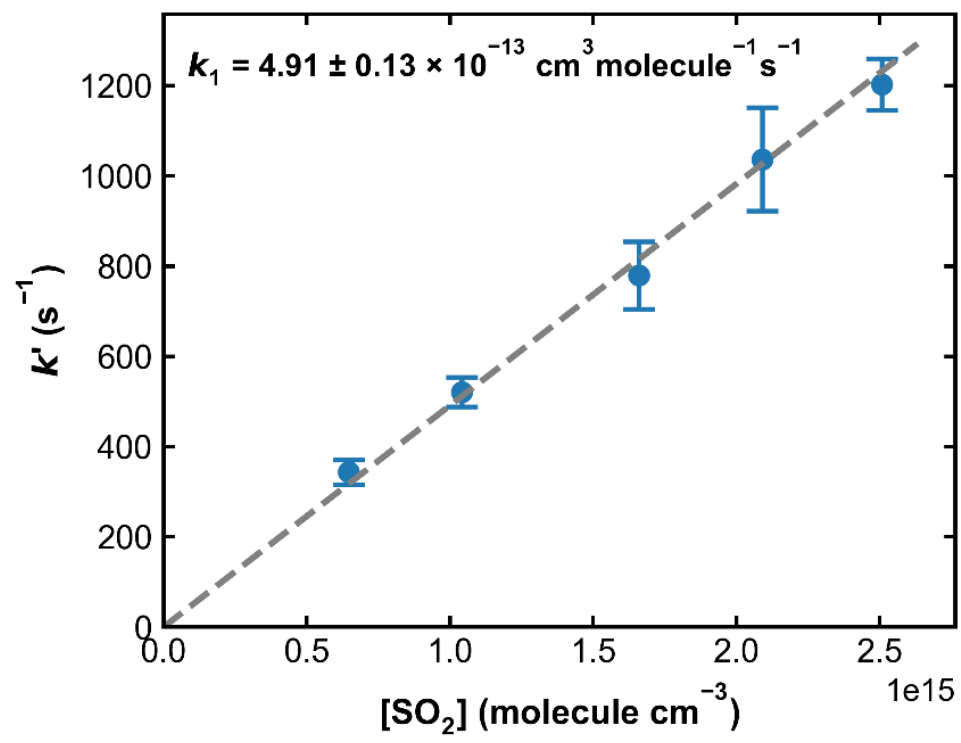

Figure 8. Pseudo-first-order rate coefficients $\left(k^{\prime}\right)$ as a function of the $\mathrm{SO}_{2}$ concentration ([ $\left.\left.\mathrm{SO}_{2}\right]\right)$ at 193.2 Torr $\mathrm{N}_{2}$ and $298 \mathrm{~K}$. OH was generated through HONO photolysis at $351 \mathrm{~nm}$. Each data point is an average over four individual measurements and the error bars represent $2 \sigma$ statistical uncertainties. $k_{1}$ was obtained from the slope of the linear regression. 
https://doi.org/10.5194/acp-2021-1074

Preprint. Discussion started: 9 February 2022

(c) Author(s) 2022. CC BY 4.0 License.

(c) (i)
Atmospheric

Chemistry

and Physics

Discussions

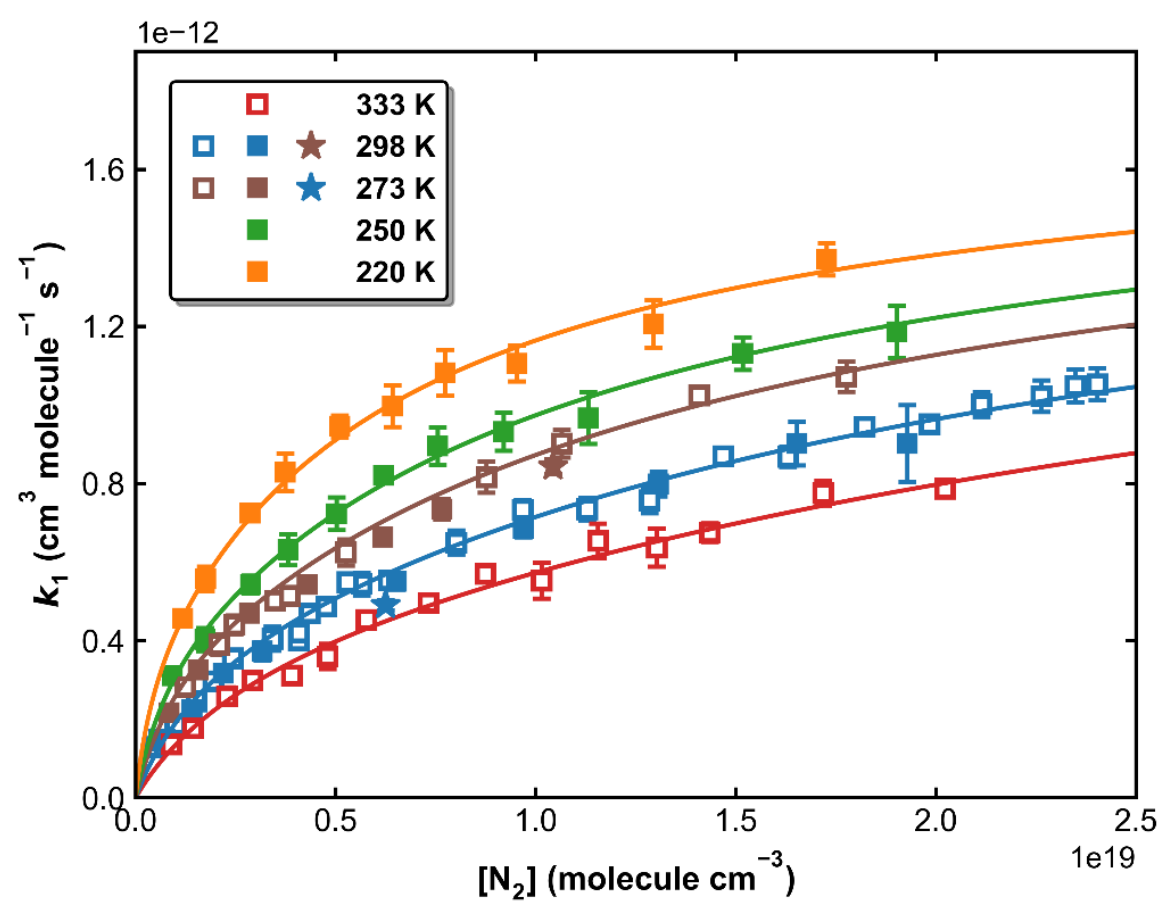

Figure 9. $k_{1}$ as a function of $\mathrm{N}_{2}$ concentration in the fall-off regime at five different temperatures. Open squares, closed squares and stars represent data obtained using $\mathrm{H}_{2} \mathrm{O}_{2}, \mathrm{HNO}_{3}$ and $\mathrm{HONO}$ as $\mathrm{OH}$ precursors, respectively. The error bars represent $2 \sigma$ statistical uncertainties. The solid lines are the fits of the experimental data to Eqn. 3 with $k_{0}=3.03 \times 10^{-31} \mathrm{~cm}^{6}$ molecule $\mathrm{s}^{-1}, k_{\infty}=2.00 \times 10^{-12} \mathrm{~cm}^{3} \mathrm{molecule} \mathrm{s}^{-1}, n=$ 4.10, $m=0$ and $F_{\mathrm{C}}=0.58$. 
https://doi.org/10.5194/acp-2021-1074

Preprint. Discussion started: 9 February 2022

(C) Author(s) 2022. CC BY 4.0 License.

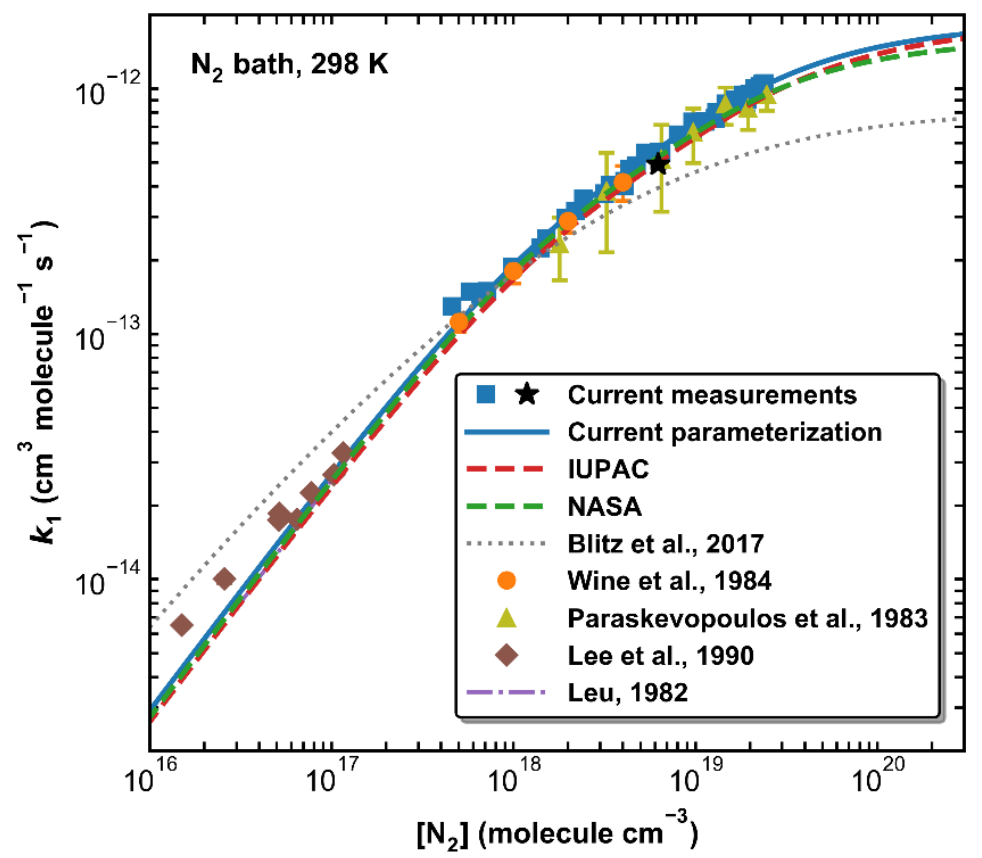

Figure 10. A comparison of previous measurements of $k_{1}$ at $298 \mathrm{~K}\left(\mathrm{~N}_{2}\right.$ bath-gas only) with our parameterisation and those of IUPAC,

615 NASA and Blitz et al. (2017b) (see Table 2 for details). The black star represents the measurement using HONO photolysis at 351 nm to generate $\mathrm{OH}$. 


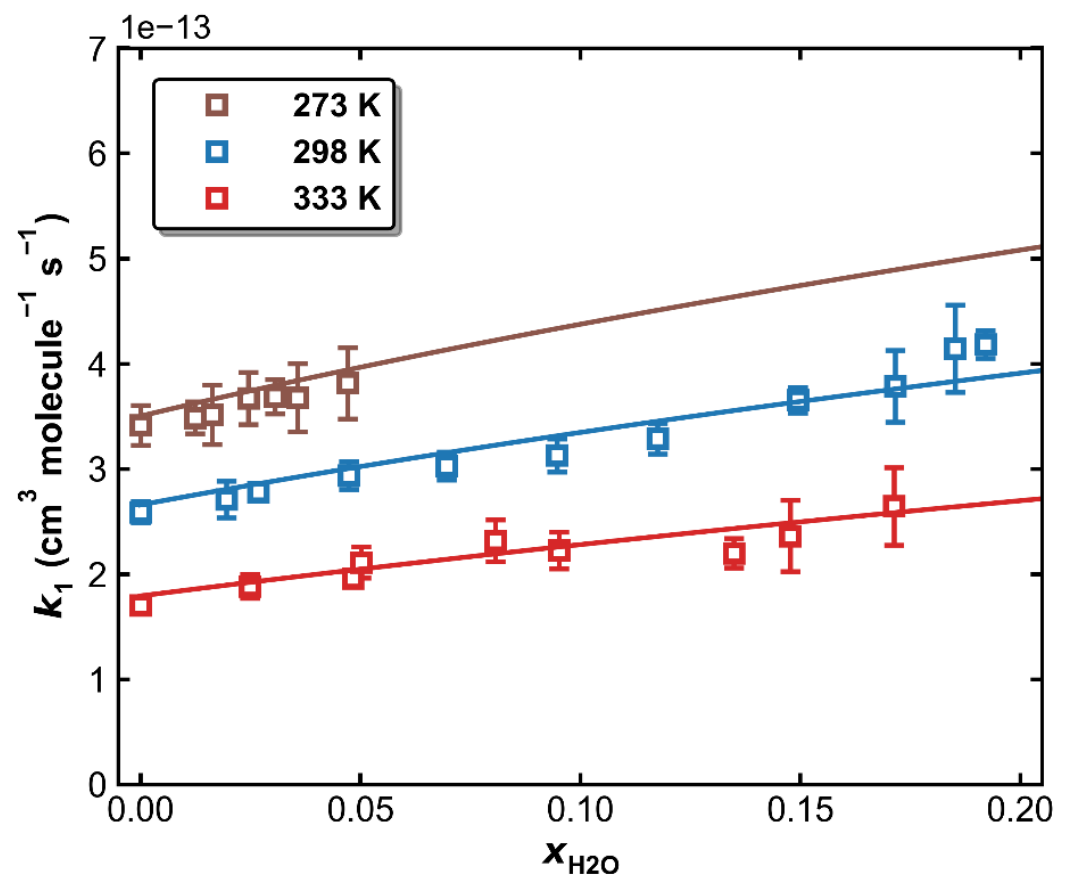

620 Figure 11. $k_{1}$ as a function of $x_{\mathrm{H}_{2} \mathrm{O}}$ in $\mathrm{N}_{2}-\mathrm{H}_{2} \mathrm{O}$ bath gas at a total pressure of 50 Torr and different temperatures of 273, 298 and $333 \mathrm{~K}$. The symbols represent measurements and the solid lines are fits to Eqn. (5) and (6) with $k_{1, \infty}=2.00 \times 10^{-12} \mathrm{~cm}^{6} \mathrm{molecule}^{-2} \mathrm{~s}^{-1}, k_{1,0}^{N_{2}}=3.03 \times 10^{-31}$ $\mathrm{cm}^{6}$ molecule $\mathrm{e}^{-2} \mathrm{~s}^{-1}, n=4.10, \mathrm{~m}=0$ and $F_{\mathrm{C}}=0.58$. The resulting parameters for water are $k_{1,0}^{H_{2} \mathrm{O}}=1.65 \times 10^{-30} \mathrm{~cm}^{6} \mathrm{molecule}^{-2} \mathrm{~s}^{-1}, o=4.90$. 
https://doi.org/10.5194/acp-2021-1074

Preprint. Discussion started: 9 February 2022

(c) Author(s) 2022. CC BY 4.0 License.

(c) (i)
Atmospheric

Chemistry

and Physics

Discussions

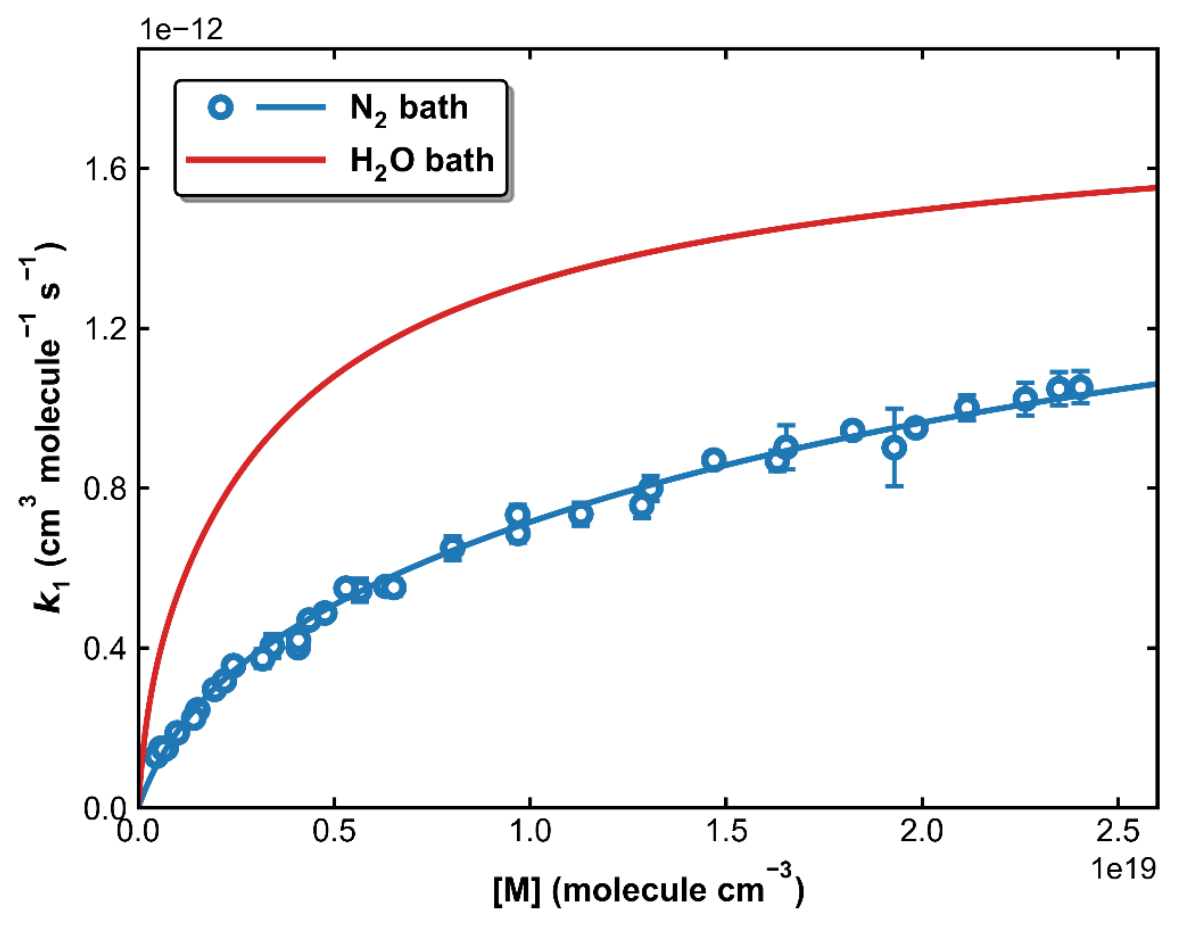

Figure 12. Fall-off curves for $k_{1}$ in $\mathrm{N}_{2}$ and $\mathrm{H}_{2} \mathrm{O}$ bath-gases at $298 \mathrm{~K}$. The solid lines are our preferred parameterization with $k_{1, \infty}=2.0 \times 10^{-12}$ $\mathrm{cm}^{3}$ molecule $\mathrm{s}^{-1}$ (independent of bath-gas), $k_{1,0}^{\mathrm{N} 2}=3.03 \times 10^{-31} \mathrm{~cm}^{6}$ molecule ${ }^{-2} \mathrm{~s}^{-1}$ and $k_{1,0}^{\mathrm{H} 2 \mathrm{O}}=1.65 \times 10^{-30} \mathrm{~cm}^{6} \mathrm{molecule}^{-2} \mathrm{~s}^{-1}, F_{C}^{\mathrm{N} 2}=F_{C}^{\mathrm{H} 20}=$ 0.58 . 
https://doi.org/10.5194/acp-2021-1074

Preprint. Discussion started: 9 February 2022

(C) Author(s) 2022. CC BY 4.0 License.

(c) (i)
Atmospheric

Chemistry

and Physics

Discussions

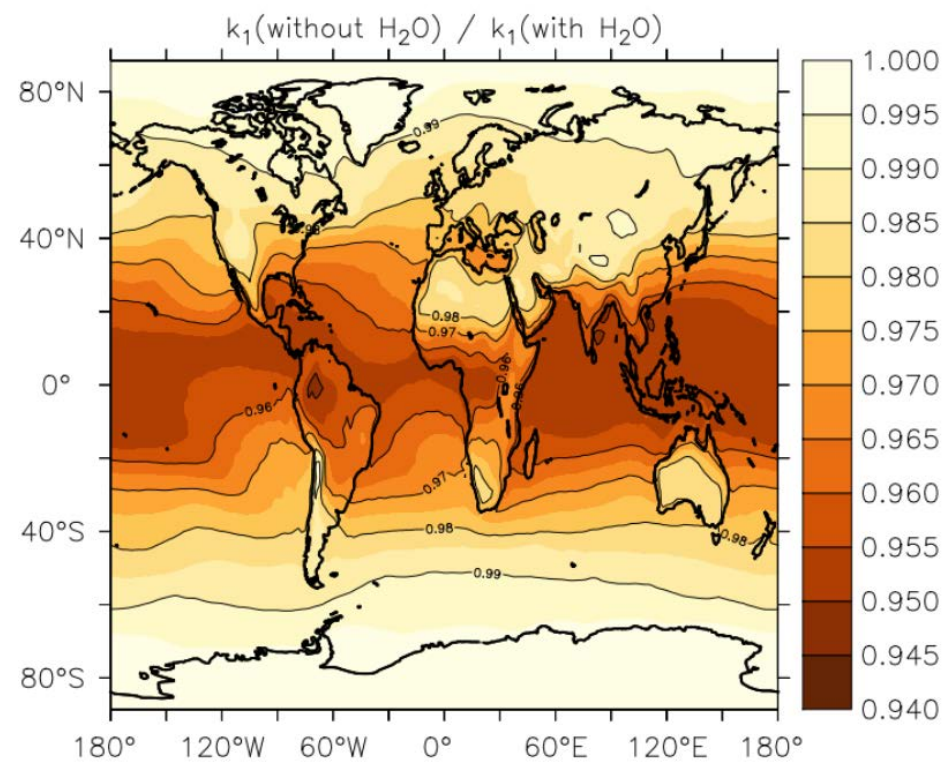

Figure 13. Annual average effect of $\mathrm{H}_{2} \mathrm{O}$ on $k_{1}$ expressed as the fractional change in the rate coefficient near the Earth's surface when setting the mole fraction of water vapour to zero in Eqn. 5 and 6. 

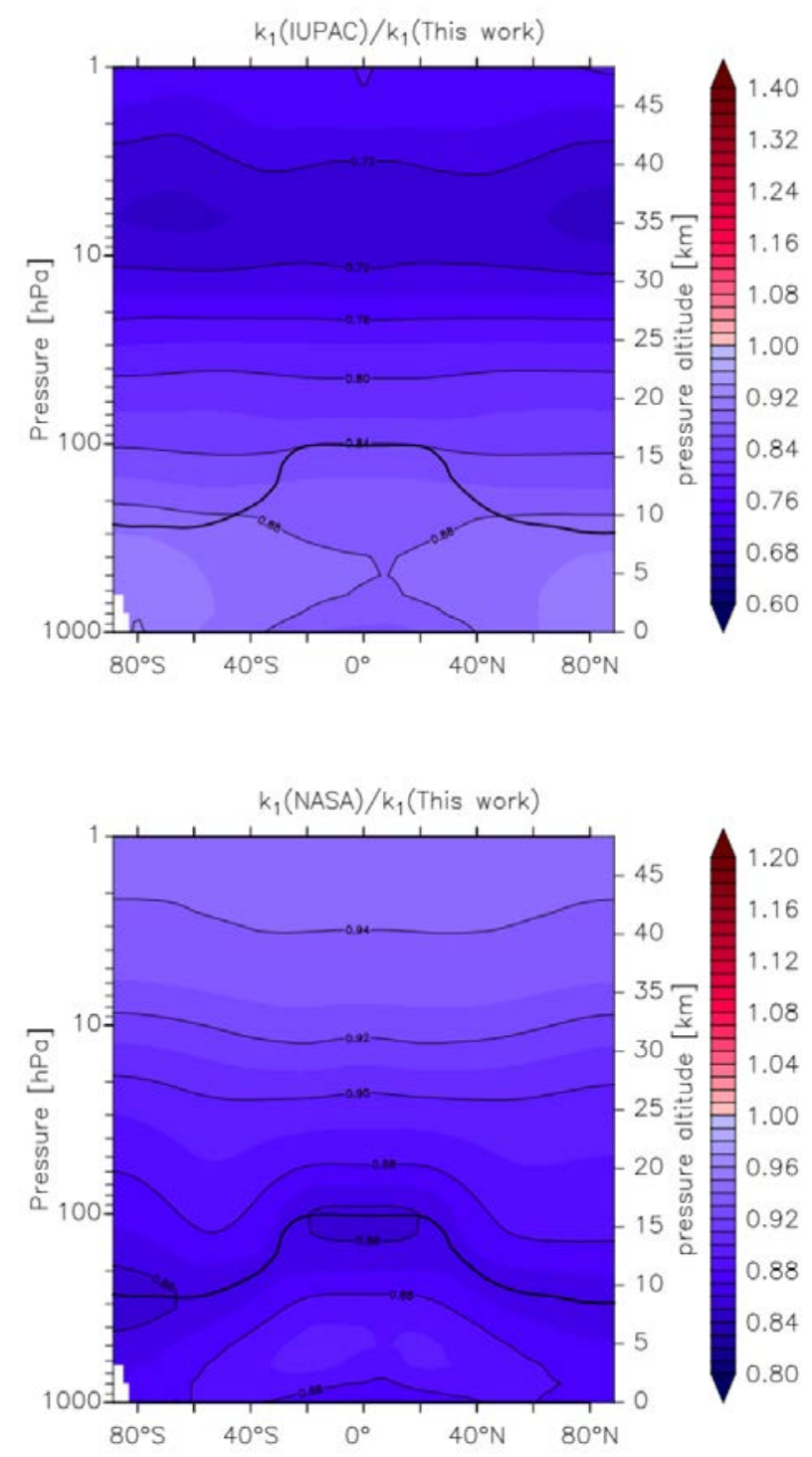

640 Figure 14. Global values of $\frac{k_{1} \text { (IUPAC) }}{k_{1} \text { (This work) }}$ (upper panel) and $\frac{k_{1} \text { (NASA) }}{k_{1} \text { (This work) }}$ (lower panel). $k_{1}$ was calculated using the parameters from this work and those presently recommended by the IUPAC and NASA data evaluation panels. The relatively thick black line between 300 and $100 \mathrm{hPa}$ represents the mean model tropopause. 

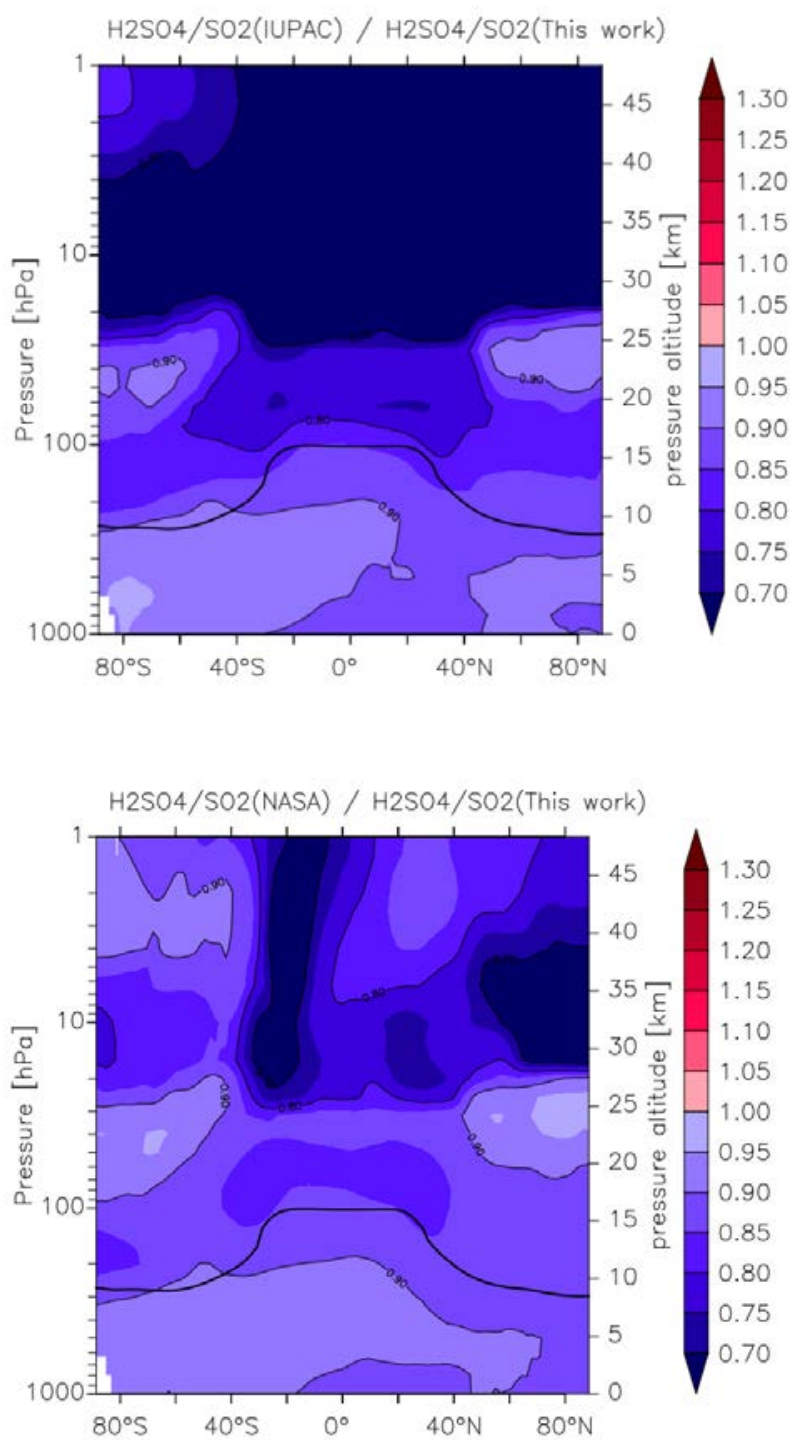

Figure 15. Effect of different parameterisations of $k_{1}$ on the global (zonal and yearly averaged) $\mathrm{H}_{2} \mathrm{SO}_{4}$ to $\mathrm{SO}_{2}$ ratio. The upper 650 panel plots $\frac{\mathrm{H} 2 \mathrm{SO} 4}{\mathrm{SO} 2}$ (IUPAC) $/ \frac{\mathrm{H} 2 \mathrm{SO} 4}{\mathrm{SO} 2}$ (this work), the lower panel plots $\frac{\mathrm{H} 2 \mathrm{SO} 4}{\mathrm{SO} 2}$ (NASA) $/ \frac{\mathrm{H} 2 \mathrm{SO} 4}{\mathrm{SO} 2}$ (this work). The relatively thick black line between 300 and $100 \mathrm{hPa}$ represents the mean model tropopause. 